\title{
THE TORT LAW DEBATE, EFFICIENCY, AND THE KINGDOM OF THE ILL: A CRITIQUE OF THE INSURANCE THEORY OF COMPENSATION
}

\author{
Ellen Smith Pryor*
}

\section{INTRODUCTION}

[I]t is hardly possible to take up one's residence in the kingdom of the ill unprejudiced by the lurid metaphors with which it has been landscaped.

- Susan Sontag ${ }^{1}$

TCORT and liability theorists do not typically reside in the "king1 dom of the ill," but of late they have at least begun to peer into it. The vigorous academic and political tort reform debate of recent years has prompted intense examination of how various legal rules advance the goals of deterrence and compensation. ${ }^{2}$ As to the latter goal, a number of noted academic and economic theorists have turned their attention to the challenging issue of how best to value and compensate injury, disease, and their consequences.

Probably the most important theme to have emerged from this literature is what this Article terms the "insurance theory of compensation." 3 Basically, the insurance theory maintains that, in many

* Visiting Professor of Law, University of Texas. Assistant Professor of Law, Southern Methodist University (on leave 1992-93). This Article benefited from the input of participants in workshops at the Center for Law and Economic Studies at Columbia University School of Law and the University of Texas School of Law. I received helpful comments from Mark Gergen, Douglas Laycock, Dick Pierce, William C. Powers, and Charles Silver. For their generous contributions of time and thought, I am especially grateful to C. Edwin Baker, Jack Balkin, Greg Crespi, and Mike Davis; for his unfailing help, I thank Will Pryor.

1 Susan Sontag, Illness as Metaphor 3-4 (1977).

2 See, e.g., Action Commission to Improve the Tort Liability System, American Bar Ass'n, Report to the House of Delegates (1987); Tort Policy Working Group, U.S. Dep't of Justice, Report of the Tort Policy Working Group on the Causes, Extent and Policy Implications of the Current Crisis in Insurance Availability and Affordability (1986); Symposium, Issues in Tort Reform, 48 Ohio St. L.J. 317 (1987); Symposium, Alternative Compensation Schemes and Tort Theory, 73 Cal. L. Rev. 548 (1985).

3 The compensation debate and the insurance theory implicate injury, disease, and their consequences. For clarification of the terminology used in this Article, see infra note 14.

In addition to the literature on which this Article focuses, other works relating to the compensatory role of payments for loss include Randall R. Bovbjerg, Frank A. Sloan \& James 
accident or compensation programs, decisions about which payments are appropriate from a compensatory perspective should turn on the types of insurance choices individuals would make in actuarially fair markets. ${ }^{4}$ The insurance theory is a significant one for both theoretical and practical reasons. First, both its theoretical underpinnings and its practical implications represent a radical departure from the most dominant existing compensation paradigm, the "make whole" mandate of tort law. ${ }^{5}$ Second, the insurance theory's potential application is very broad: its detailed and specific maxims could be applied in a wide variety of programmatic contexts (such as tort reform and social insurance programs). Third, key participants in the compensation debate have approved of the theory. For example, the insurance theory has received at least qualified approval from numerous prominent voices, including law and economics scholars such as Professor Steven Shavell, ${ }^{6}$ respected economic and empirical analysts like W.

F. Blumstein, Valuing Life and Limb in Tort: Scheduling "Pain and Suffering," 83 Nw. U. L. Rev. 908 (1989); David W. Leebron, Final Moments: Damages for Pain and Suffering Prior to Death, 64 N.Y.U. L. Rev. 256 (1989); Ted R. Miller, Willingness to Pay Comes of Age: Will the System Survive?, 83 Nw. U. L. Rev. 876 (1989).

4 See infra text accompanying notes 18-27.

5 See generally Graham Douthwaite, Jury Instructions on Damages in Tort Actions 3 (2d ed. 1988) (describing a representative jury charge as instructing the jury that " $[t]$ he object of an award of damages is to place the plaintiff, as far as money can do it, in the situation he would have occupied if the wrong had not been committed"); Fowler V. Harper, Fleming James, Jr. \& Oscar S. Gray, The Law of Torts $\S 25.1$, at 493 (2d ed. 1986) (discussing the traditional tort approach). This is not to say that the tort system actually or usually provides complete or "make whole" compensation in practice. See, e.g., Stanley Ingber, Rethinking Intangible Injuries: A Focus on Remedy, 73 Cal. L. Rev. 772, 775 (1985) (stating that the "tort system does not ... purport to redress all material losses, physical or mental").

6 See Steven Shavell, Economic Analysis of Accident Law 206-61 (1987). Professor Shavell begins his discussion with the observation that "the accident problem involves not only the goal of reducing appropriately the risks of accident losses, but also the objective of properly allocating those accident losses that do occur." Id. at 206. He treats the insurance theory of compensation within his discussion of "liability awards that are optimal for purposes of compensation." Id. at 228. Although he does not specifically argue that the insurance theory could and should be implemented in all of its detail, he clearly views the theory as having prescriptive force for the analysis and design of real-world programs. For example, he uses the theory to critique the existing liability regime, id. at 231-32, and to propose an alternative approach: supplementing optimal compensatory awards with deterrence fines. Id. at 233-34. 
Kip Viscusi ${ }^{7}$ and Patricia Danzon, ${ }^{8}$ tort theorists such as Professor Alan Schwartz, ${ }^{9}$ and the American Law Institute's Reporters' Study on Enterprise Responsibility for Personal Injury, released in April of 1991. ${ }^{10}$ Although the commentators disagree about certain particu-

7 See W. Kip Viscusi, Reforming Products Liability 89-94 (1991) [hereinafter Viscusi, Reforming Products Liability] (arguing that the insurance theory is appropriate with respect to a compensation as opposed to a deterrence aim); W. Kip Viscusi \& William N. Evans, Utility Functions That Depend on Health Status: Estimates and Economic Implications, 80 Am. Econ. Rev. 353 (1990) (describing the results of an empirical study aimed at providing data for use in implementing the insurance theory); W. Kip Viscusi, Toward a Diminished Role for Tort Liability: Social Insurance, Government Regulation, and Contemporary Risks to Health and Safety, 6 Yale J. on Reg. 65, 93 (1989) [hereinafter Viscusi, Toward a Diminished Role for Tort Liability] (noting that a "common benchmark of appropriate compensation is the amount of insurance an individual would purchase at actuarially fair prices"). Viscusi, a professor of economics at Duke University, was a reporter for the American Law Institute's project concerning enterprise responsibility for personal injury. See 1 American Law Inst., Reporters' Study on Enterprise Responsibility for Personal Injury: The Institutional Framework (1991) [hereinafter 1 ALI Reporters' Study].

8 See Patricia M. Danzon, Tort Reform and the Role of Government in Private Insurance Markets, 13 J. Legal Stud. 517, 520-26 (1984) [hereinafter Danzon, Tort Reform]. Danzon endorses the insurance theory as delineating the type of payments that are efficient. See id. at 518-19. She does not, however, take a position on whether efficiency considerations alone should determine compensation policy. See Patricia M. Danzon, Medical Malpractice: Theory, Evidence, and Public Policy 10 (1985) [hereinafter Danzon, Medical Malpractice] (noting that the term "optimal" as used in her book refers to economic efficiency, but also stating that "[w]hether economic efficiency is or should be the only criterion for evaluating social policy toward injuries is not debated here"). Hence, one could interpret her work as a qualified endorsement of the theory: that is, as an assertion that insurance theory is appropriate to the extent that efficiency considerations should determine compensation policy. As I will show, even such a qualified endorsement of the theory should fail. See infra text accompanying notes $135-48$.

9 Alan Schwartz, Proposals for Products Liability Reform: A Theoretical Synthesis, 97 Yale L.J. 353, 362-67 (1988). Professor Schwartz endorses use of a "consumer sovereignty" maxim in evaluating liability and damage rules for product-related injuries. Id. at 355-59. He argues that such a maxim would support use of the insurance theory's approach to awarding damages. Id. at 362-67.

102 American Law Inst., Reporters' Study on Enterprise Responsibility for Personal Injury: Approaches to Legal and Institutional Change (1991) [hereinafter 2 ALI Reporters' Study]. The study, which was released in April 1991, discusses the insurance theory of compensation in its analysis of damage awards for pain and suffering under current tort law. It cites the insurance literature and also notes that "[e]mpirical corroboration of these analytical claims" can now be found. Id. at $206 \mathrm{n}$.13. (I challenge this conclusion and later criticize the study on which it is based. See infra Part II.A.) The ALI Study states that from a purely compensatory perspective the literature espousing the insurance theory is a "particularly compelling" critique of much that currently falls under the heading of pain and suffering. Id. at 209. Yet, the reporters go on to suggest that redistributive principles could support some payments for nonpecuniary losses to victims of severe disability when those payments would assist in adjustment to disability. Id. at 210-11. Ultimately, the study does not take a firm position on 
lars of the theory, most seem to agree that the theory has substantial merit from a compensatory perspective.

This Article critiques and in large measure rejects the insurance theory of compensation. ${ }^{11}$ In it, I argue that the theory has fundamental failings - both normative and practical - that render it untenable as a primary guide to determining the appropriate compensatory sums in any programmatic setting. This is true even when the theory is judged solely on the basis of compensatory and not deterrence considerations. ${ }^{12}$ Many of these failings, I will show, stem from the theory's failure to engage meaningfully with the kingdom of the ill and the disabled. ${ }^{13}$ At critical turns the insurance theory, as expounded in

the merits of the insurance theory. See id. at 216. For a detailed discussion of the ALI study, see Stephen D. Sugarman, A Restatement of Torts, 44 Stan. L. Rev. 1163 (1992) (book review).

Professor Paul Weiler, one of the chief architects of this ALI study, has articulated similar views in his recent book on medical malpractice. See Paul C. Weiler, Medical Malpractice on Trial 56-58 (1991). He argues that nonpecuniary payments might be justified when they help provide for "rehabilitation and support in the broader sense of the term, helping the accident victim to adjust socially and psychologically, rather than just medically and vocationally to the new disabled state." Id. at 58. Although I agree with his statement, I further argue that the insurance theory is indeterminate with respect to critical decisions about which postinjury expenditures are warranted and which are not. See infra text accompanying notes 113-32. As I elaborate later, I also reject any effort to base such decisions on conclusions about marginal utility. See infra text accompanying notes 52-112.

11 In her pathbreaking article on rape, Susan Estrich wrote that she "[could] not imagine anyong writing an article on prosecutorial discretion without disclosing that he or she had been a prosecutor." Susan Estrich, Rape, 95 Yale L.J. 1087, 1089 (1986). Her point is a powerful one, and so I should mention some experiences that have played a role in my thinking about disability. Several years ago, I was involved in a serious accident that resulted in a lengthy period of hospitalization and rehabilitation. In addition, during several years of law practice, I primarily represented disabled clients with respect to a variety of compensation and "rights-oriented" claims: social security disability, federal civil-service disability, federal and state workers' compensation, state and federal discrimination claims, and some traditional tort claims. I still have not sorted out all the lessons of those experiences, nor have I answered for myself all of the fascinating and difficult questions raised by the literature relating to the role of voice and narrative in legal scholarship. See infra note 13. Although I remain unclear about the influence of my experiences on my personal and professional perspectives, it seemed appropriate to mention them now, because I have felt their tug more during the writing of this Article than during any other scholarly work that I have done.

12 Because the insurance theory addresses the question of what payments are appropriate only from a compensatory perspective, relying solely on that theory to determine damage amounts raises obvious deterrence concerns. Much of the literature discusses these concerns. See infra notes 17 and 43 . I argue that the insurance theory of compensation is inadequate, even when viewed from a compensatory perspective alone.

13 Susan Sontag's phrase appears in her brilliant discussion of how illness-particularly diseases such as tuberculosis and cancer-has been "encumbered by the trappings of 
the literature, relies on disability-related assumptions and conclusions that, I will argue, are indefensible when considered in light of the narrative, psychological, sociological, and empirical literature relating to injury, disease, impairment, disability, and handicap. ${ }^{14}$ For example, this Article challenges the insurance theory's assumptions and conclusions about the nature and quality of life in various states of disability, the uses of money in a state of disability, the merits of relying on the views of the nondisabled with respect to disability, and the ability to categorize the vast and complex spectrum of losses into a dichotomy between pecuniary and nonpecuniary losses.

metaphor." Sontag, supra note 1, at 5. Although she focuses on illness, I use her phrase because many of her insights apply equally well to the experience of disability. For example, she writes about the guilt and shame that attaches to certain illnesses: "[T]he subjects of deepest dread (corruption, decay, pollution, anomie, weakness) are identified with the disease. The disease itself becomes a metaphor. Then, in the name of the disease (that is, using it as a metaphor), that horror is imposed on other things." Id. at 58. The anthropologist Robert Murphy, in his powerful discussion of his own disability and disability generally, also writes about how disability becomes identified with guilt and shame. See Robert F. Murphy, The Body Silent 92-97 (1990).

My hope is that listening more carefully to the voices of disabled individuals will provide insights that bear on, and bring us to reject, the insurance theory of compensation. Cf. Mark G. Yudof, "Tea at the Palaz of Hoon": The Human Voice in Legal Rules, 66 Tex. L. Rev. 589, 591 (1988) (agreeing that "neglected human voices may be blended and fashioned into new and better rules as part of the process of reexamination, justification, and change"). I do not argue that greater attention to the kingdom of the disabled is somehow incompatible with legal rules relating to disability. Cf. Toni M. Massaro, Empathy, Legal Storytelling, and the Rule of Law: New Words, Old Wounds?, 87 Mich. L. Rev. 2099, 2116 (stating that "the rule-of-law model and empathy are not natural, inevitable antagonists"); Yudof, supra, at 620 (arguing that "there is no inherent inconsistency between legal rules and the voices of human experience, suffering, and needs"). Still worthy of further exploration, however, are some difficult questions about voice and disability-related legal structures. For example, when, if ever, should the voices and perspectives of the disabled trump those of the nondisabled with respect to disability-related decisions or rules? These and some other important issues relating to the voices of disability are outside the scope of this Article, but I hope to explore them elsewhere.

${ }^{14}$ This terminology follows the approach of the World Health Organization. See World Health Org., International Classification of Impairments, Disabilities, and Handicaps 27-31 (1980). Injury and disease refer to the physiological or psychological events that begin the process of loss. The next three terms refer to the permanent consequences that may follow an injury or disease. Impairment refers to a functional or cosmetic alteration at the organ level, such as a scar or restricted range of motion in the hand or knee. Id. at 27. Disability (or "whole-person impairment") refers to functional consequences at the whole-person level, such as restricted ability to walk, bend, or lift. Id. at 28 . Handicap also refers to whole-person consequences, but includes the social impacts of those consequences, such as the inability to work, drive, or interact with other people. Id. at 29. At times, I use the terms "the disabled" or "the disabled world" to refer generically to this whole set of permanent consequences. 
Part I of this Article explains the insurance theory in detail. It concludes that the theory now represents a full-bodied compensation approach that its adherents implicitly or explicitly endorse in many or most programmatic contexts. Parts II and III focus, respectively, on the two features of the theory that are most crucial to its working: (1) how an injury or disease affects the marginal utility of money and (2) the distinction between "pecuniary" and "nonpecuniary" losses.

Because the marginal utility determination is perhaps the key feature of the insurance theory, Part II addresses whether and how a compensation program could arrive at and implement an answer to that query. Although the existing literature often supposes that a satisfactory answer already exists, the empirical work to date has a fatal problem: it rests simply on the assumptions of the nondisabled about the nature and quality of a disabled person's life. Drawing on the psychological, empirical, and narrative literature relating to disability, Part II outlines the reasons why the nondisabled perspective is inappropriate: the nondisabled lack significant information about disability; devaluation of the disabled likely will play a role in pre-injury attitudes about disability; and the process of serious loss is often transformative in a way that renders obsolete even informed, nondevaluative pre-injury opinions about disability.

The analysis in Part II then turns to the possibility of basing marginal utility conclusions on the perspectives of the disabled. Although this initially appears to be a more promising approach, it ultimately fails as well, because the answers of the disabled to the marginal utility query are likely to reflect prevalent societal discrimination against and devaluation of the disabled. For example, a burn victim who suffers disfiguring scars might "correctly" decide that money has been far less valuable after her injury, because the attitudinal barriers she faces on a daily basis render her postinjury activities less pleasurable. The insurance theory frequently would translate such opinions into reduced levels of compensation, in a context-disability-where money determines fundamental quality of life issues such as independence, transportation, recreation, education, and vocational abilities. In short, the insurance theory accepts existing disability-related preferences-which are in part the product of unfairly reduced opportunities available to the disabled-and then uses those preferences to justify a compensation approach that often would further diminish the scope of opportunity for the disabled. 
Part III turns to the other key feature of the insurance theory: the distinction between pecuniary and nonpecuniary losses. In practice, this distinction will largely determine the presumptive compensability status of items such as medical care, independent living services, adaptive technology, and rehabilitation services. Thus, one can fairly demand that the insurance theory give meaningful direction about how to confront these choices. Yet, the theory does not give such direction; instead, the distinction between pecuniary and nonpecuniary losses seems likely in many cases to require evaluative standards that the theory does not provide. In addition to this problem of indeterminacy, the distinction raises a concern similar to that explored in Part II, because the classification of a loss under one heading or the other may be affected by disability-related preferences that themselves are the product of discrimination and devaluation.

Taken together, Parts II and III demonstrate practical and normative problems that justify rejection of the insurance theory of compensation, whatever the normative foundation on which it is claimed to rest. Part IV explores in more detail the various normative arguments that might be advanced on the theory's behalf, and illustrates some of the most salient problems with these arguments. I begin by considering what might seem the most intuitively persuasive defense of the theory: when a program (such as the tort system) basically functions as an insurance system, surely it is appropriate to model the program according to insurance-related criteria. At best, however, this defense only justifies the insurance theory's use as a general, fairly rough critique of the tort system's currently extensive levels of noneconomic compensation. As I argue in Part III, the theory still fails to yield meaningful guidance about the standards that should replace current laws governing tort damages.

Part IV next shows that, to the extent the insurance theory rests on an efficiency norm, the theory fails even on its own terms. This is true because the theory's focus on intrapersonal loss-spreading does not consider a number of external costs of illness or injury. Finally, Part IV explores arguments from autonomy and contractarian values that might support the theory. It demonstrates that the theory's reliance on existing disability-related preferences undermines any persuasive autonomy-based defense. As to contractarian arguments, the insurance theory is troublesome in light of virtually any meta principle that might be derived from that perspective. 
Although some of the Article's discussion must take place on the relatively abstract and theoretical level of the insurance theory's literature, the central source of the Article's criticisms is the kingdom of the ill and the disabled and the lessons it can yield. Familiarity with the "lurid metaphors" associated with that kingdom exposes the shortcomings of existing data purporting to document a marginal utility conclusion. Some knowledge of the complex and varied nature of injury and its consequences allows one to see the significant obstacles to finding and implementing a marginal utility conclusion, as well as the inadequacy of risk-spreading from a purely intrapersonal perspective. An appreciation of the ways that society devalues and discriminates with respect to disability gives rise to grave doubts about the ways in which the theory makes use of existing disability-related preferences. Finally, an understanding of how and why money is central to the well-being of the disabled allows a better understanding of the personal and distributional impacts of the insurance theory of compensation.

Despite its fundamental rejection of the theory, the Article concludes by reflecting on the various ways in which that theory has proven or might prove useful. The insurance theory has underlined the usefulness of separately analyzing the deterrent and compensatory roles of payments for loss. It has drawn significant scholarly attention to the traditionally less-examined aim of compensation. And, however imperfectly, it has at least begun to raise important questions that have been obscured by the traditional tort paradigm: when and how money can benefit the injured and diseased, and how significant those benefits are in various contexts.

This Article's rejection of the insurance theory should not be read as an endorsement of the tort system's current "make whole" compensation paradigm; indeed, that paradigm also deserves rejection, although the topic is beyond the scope of this Article. ${ }^{15}$ Instead, I hope that an understanding and eventual rejection of the insurance

15 It is possible to reject the insurance theory as a primary guide to determining the amount and types of compensation that should be payable and nonetheless agree that the tort law's current approach to compensation for noneconomical losses is problematic. See infra notes 179 and 181. Of the literature that draws on the insights of the insurance theory, a recent article by Professors Calfee and Rubin is probably the most detailed in its criticism of tort law's current levels of noneconomic compensation. See John E. Calfee \& Paul H. Rubin, Some Implications of Damage Payments for Nonpecuniary Losses, 21 J. Legal Stud. 371 (1992). 
theory will advance the construction of compensatory approaches different from those of both tort and the insurance theory.

\section{The Insurance Theory of COMPENSATION}

\section{A. The Theory Described}

Payments for loss, of course, can have both deterrent and compensatory roles, and payments proper for deterrence purposes may not be identical to payments proper for compensation purposes. Hence, the question of appropriate compensation can be considered separately from the question of appropriate deterrence. ${ }^{16}$ The insurance theory purports only to answer the former question: it delineates which payments are warranted solely for compensatory purposes. ${ }^{17}$

The theory arises from the quite defensible observation that most societal compensation programs, including the tort system, currently function to a large extent as insurance programs. ${ }^{18}$ As the ALI Reporter's Study asserts, tort law may be pictured "as a port of entry into an insurance program paid for and provided by members of the community for themselves." 19 Given this, proponents of the insurance theory argue, it makes sense to construct compensation guidelines that follow insurance principles. ${ }^{20}$ If individuals are funding systems that function as insurance programs, we should try to deter-

16 See Shavell, supra note 6, at 23i-33. See generally Guido Calabresi, The Costs of Accidents: A Legal and Economic Analysis (1970) (elaborating on the distinct goals of reducing accidents and reducing the costs of accidents that occur).

17 See Viscusi, Reforming Products Liability, supra note 7, at 89-90. Indeed, the literature frequently notes that the optimal compensatory sum may be inadequate from a deterrence perspective. See, e.g., Shavell, supra note 6, at 231-33; Danzon, Tort Reform, supra note 8, at 521. For this reason, some commentators have proposed adding a fine or surcharge to the sum that the injurer must pay. See, e.g., Shavell, supra note 6, at 233-34; Danzon, Tort Reform, supra note 8 , at 521 . Others have argued that the compensatory amounts suggested by insurance theory could, in appropriate cases, be modified to take deterrence concerns into account. See, e.g., Viscusi, Reforming Products Liability, supra note 7, at 89-94.

$18 \mathrm{~A}$ forceful and lucid presentation of this view appears in Paul Weiler's book on medical malpractice. See Weiler, supra note 10, at 44-47.

192 ALI Reporters' Study, supra note 10, at 206.

20 Id. at 205-07; Danzon, Tort Reform, supra note 8, at 520; cf. George L. Priest, The Current Insurance Crisis and Modern Tort Law, 96 Yale L.J. 1521, 1556 (1987) (stating that when the victim is the purchaser of a product or service, the victim must pay in advance for insurance and that " $[t]$ o compel insurance greater than the amount demanded by the purchaser reduces, rather than increases, his or her welfare"). 


\section{mine the types and levels of insurance that individuals actually would want. $^{21}$}

Starting with this premise, insurance theorists posit that the optimal compensatory sum is the amount of insurance that individuals would have purchased in an actuarially fair ${ }^{22}$ insurance market. ${ }^{23}$ Because complete, actuarially fair insurance markets do not exist, ${ }^{24}$ the theory obviously is not governed by existing private choices, but rather by its account of what individuals would choose if such markets did exist. ${ }^{25}$ According to the theory, a utility-maximizing individual would incur the expense of an insurance premium if, by

21 Of course, one could question this starting point-that individuals fund insurance systems - as a normative matter. The insurance theory, however, provides a more practical critique of existing compensation systems, and it deserves to be answered on its own terms. In any event, the theory's starting point is not wholly arbitrary. The tort system and other compensation programs do function to an extent as insurance schemes; participants do pay, in effect, premium dollars. Thus, the notion that we should consult individual preferences about these tort-compelled insurance premiums has some plausibility. Nonetheless, as I argue in more detail later, this starting notion, even if one agrees with it, falls far short of justifying use of the insurance theory as a primary guide to real-world compensation programs.

22 An actuarially fair insurance premium is one that equals the insured's expected accident costs-that is, the costs of an accident multiplied by the probability of its occurence. Jon D. Hanson \& Kyle D. Logue, The First-Party Insurance Externality: An Economic Justification for Enterprise Liability, 76 Cornell L. Rev. 129, 138 n.40 (1990). For example, if the insured faces a $5 \%$ risk of losing $\$ 10,000$, an actuarially fair premium for full insurance coverage would be $\$ 500$. Shavell, supra note 6 , at $192 \&$ n. 10 .

23 See Shavell, supra note 6, at 228-31; Danzon, Tort Reform, supra note 8, at 520; Hanson \& Logue, supra note 22 , at 182 (referring to the "well-accepted assumption that damage awards for accident losses should equal the amount of insurance consumers would have purchased ex ante"); Priest, supra note 20, at 1556-57; Schwartz, supra note 9, at 362-63 (arguing for this approach in the context of product-related injuries). See generally Philip J. Cook \& Daniel A. Graham, The Demand for Insurance and Protection: The Case of Irreplaceable Commodities, 91 Q.J. Econ. 143 (1977) (one of the seminal articles relating to the insurance theory). Cook \& Graham are almost always cited for some of the basics of the theory. See, e.g., Shavell, supra note 6, at 231; Danzon, Tort Reform, supra note 8, at 520; Hanson \& Logue, supra note 22, at 182 n.198; Schwartz, supra note 9, at 362 n.13.

${ }^{24}$ Factors such as moral hazard, adverse selection, and inaccurate perceptions of risk prevent the existence of complete, actuarially fair insurance markets. See Viscusi, Toward a Diminished Role for Tort Liability, supra note 7, at 67-68.

25 The literature has, however, drawn on existing insurance patterns for evidence relating to specific elements of the insurance theory. See, e.g., Jennifer H. Arlen, Reconsidering Efficient Tort Rules for Personal Injury: The Case of Single Activity Accidents, $32 \mathrm{Wm}$. \& Mary L. Rev. 41, $73 \mathrm{n} .149$ (1990) (arguing that existing insurance markets suggest that physical injuries affect the victim's marginal utility of wealth, but noting that the empirical question remains unanswered); Danzon, Tort Reform, supra note 8, at 522-24 (relying on existing private and social insurance as indications of whether disability lowers or raises the marginal utility of wealth). 
transferring dollars from the preloss state to the postloss state (via the insurance policy purchase), she would be transferring wealth from a state in which it yields less utility (the preloss state) to one in which it yields more (the postloss state). ${ }^{26}$ In fact, she would continue to make such transfers until the marginal utility of money in the preloss state was the same as in the expected postloss state. ${ }^{27}$ Once she reached that position of equality, she could no longer increase expected utility by transferring dollars to the postloss state. Hence, she would purchase no more insurance.

Insurance theorists then apply these general guidelines to determine the insurance decisions that individuals would make as to specific sorts of potential losses. First, consider an injury that causes only monetary loss, such as an injury that reduces or eliminates an individual's wage-earning capacity. In the postloss (reduced income) state, the marginal utility of money will be higher than it was in the preloss state, because the marginal utility of money to a given individual is assumed to decline with greater wealth and increase with reductions in wealth. ${ }^{28}$ In most cases, then, an individual can increase expected utility by purchasing insurance covering the full monetary loss. ${ }^{29}$ Accordingly, the insurance theory maintains that coverage for the full loss is appropriate when an injury causes solely monetary losses. ${ }^{30}$

Second, and more difficult, are decisions about efficient insurance coverage when losses are not solely monetary. Nonmonetary losses, of course, include losses such as physical pain, mental anguish, physical impairment (such as the inability to play sports), and disfigurement. The insurance theory gives far less support to coverage for such losses than for monetary losses. This lack of support rests on several rationales.

The primary rationale for this exclusion is that, unlike pecuniary losses (which, by lowering wealth, increase the marginal utility of money), nonpecuniary losses cannot readily be presumed to increase the marginal utility of money. Professor Shavell gives as an example

26 See Schwartz, supra note 9, at 362-63.

27 See Arlen, supra note 25, at 73; Schwartz, supra note 9, at 363.

28 See Shavell, supra note 6, at 186-87; Schwartz, supra note 9, at 363.

29 See Schwartz, supra note 9, at 363.

30 See Shavell, supra note 6, at 193; Schwartz, supra note 9, at 363. This does not complete the story, however, because the nonpecuniary aspects of injury may affect the marginal utility of wealth. 
the loss of an irreplaceable family portrait, which results in a significant emotional loss. ${ }^{31}$ This loss, although real, is not likely to affect the family member's need for money, as would, for example, the loss of earning capacity. If a loss will not increase the marginal utility of money, the purchase of insurance coverage for that loss cannot increase expected utility and, thus, is not efficient. ${ }^{32}$

Indeed, some insurance theorists point out that nonpecuniary losses might reduce the marginal utility of money, rather than leave it unaffected. For example, an individual suffering chronic and severe pain might derive less utility from the same level of wealth after her loss than she derived before it. If so, this would reduce even the pecuniary loss coverage that the individual will purchase. Recall that, according to the insurance theory, an individual will purchase full coverage for pecuniary loss because that loss will increase the marginal utility of money in the postloss state. If, however, the nonpecuniary impacts of an injury reduce the marginal utility of money, then the individual's incentive is to keep more dollars for use in the preloss state. ${ }^{33}$

Finally, insurance theorists note that the nonpecuniary impact of an injury may increase the marginal utility of money. ${ }^{34}$ For example, an individual's reduced ability to play tennis may enhance the value of expenditures relating to remaining abilities, such as the ability to travel. In such cases, one could argue, optimal insurance will not be limited to pecuniary loss, but will cover nonpecuniary loss to the extent that it increases the marginal utility of money. Thus, some coverage for such nonpecuniary losses is appropriate, at least according to some insurance theorists. ${ }^{35}$

At least one scholar, however, advances a rationale for denying coverage of nonpecuniary losses-even those that increase the marginal utility of money. Professor Schwartz argues that an injury increases the marginal utility of money if it will cause the individual to substitute more expensive activities to replace the utility loss caused by the nonpecuniary loss-for example, an individual who can no longer jog might substitute travel or the symphony (more expen-

\footnotetext{
31 Shavell, supra note 6, at 228.

32 See id. at 229; Schwartz, supra note 9, at 364.

33 See Shavell, supra note 6, at 230; Schwartz, supra note 9, at 364.

34 See, e.g., Shavell, supra note 6, at 228; Schwartz, supra note 9, at 364.

35 See Shavell, supra note 6 , at 230 . This is not to say that optimal insurance would cover all nonpecuniary losses.
} 
sive) to replace the utility lost by her inability to jog (less expensive). ${ }^{36}$ But, he argues, "income effects" enter the calculus at this point. ${ }^{37}$ That is, for substitute activities, as for most goods and services, demand increases as wealth increases and decreases as wealth decreases. ${ }^{38}$ Because "accidents make people poorer in a utility sense," an individual's normal demand for goods and services will decrease after an injury or illness. ${ }^{39}$ Hence, an individual deciding about insurance for substitute expenses can anticipate being willing to spend less on such substitutes in the postloss state than she would be willing to spend preloss. ${ }^{40}$ Informed insurance consumers, therefore, will purchase less than full coverage for nonpecuniary loss even with respect to losses that increase the marginal utility of money. ${ }^{41}$

36 Schwartz, supra note 9 , at 364 .

37 Id. at 365 . The argument is helpfully restated and elaborated in Hanson \& Logue, supra note 22, at 184-85. Hanson \& Logue go on to criticize Professor Schwartz's position. See id. at 185-86. For my criticism of Schwartz's argument, see infra note 41.

38 See Schwartz, supra note 9, at 366.

39 Id.

40 See id.

41 Although Professor Schwartz attributes this result to "income effects," his argument actually only begins with income effects and ends with something else. The first move in his argument is to cite the well-accepted version of income effects: for most goods, consumption will increase as wealth increases. Schwartz, supra note 9, at 366 . He then equates a decrease in health with a decrease in wealth: "accidents make people poorer in a utility sense." Id. This allows him to conclude that decreases in health, like decreases in wealth, are linked to a decline in consumption. Although he makes use of income effects, the argument ultimately attributes this consumption decline not to the fact that the individual is poorer, but to the fact that the disability has made the individual more miserable. This is a "disability effect," not a wealth effect.

Professor Schwartz, however, offers little support for the crucial move in his argument: that decreases in health will result in consumption decreases. Of course, these two results often will accompany each other because serious decreases in health usually reduce the person's pecuniary wealth, which in turn will result in decreased consumption. But this hardly proves his implicit contention that poorer health, independently of its effect on wealth, reduces consumption.

Another "disability effect" argument is that poorer health, like decreased wealth, reduces overall utility. Thus, one might argue, poorer health can be assumed to have the consumption effect of decreased wealth. But neither Schwartz's article nor any of the empirical or disability literature supports this assumption. Given equal levels of wealth, a disabled person might well engage in more extensive consumption than a nondisabled one.

Another interpretation of Professor Schwartz's argument is possible. By contending that "accidents make people poorer in a utility sense," id. at 366 , he may mean only that accidents usually lower wealth and thus cause decreases in consumption. If this is his point, then his argument does turn on income effects as usually understood, rather than on a disability effect. The income effect argument would proceed as follows. The utility-maximizing individual must decide how much insurance to purchase. She can anticipate that an accident will ultimately 
In sum, the insurance theory leads to the following conclusions about optimal insurance coverage: (1) when an injury has only pecuniary impacts, then full coverage is efficient; (2) when an injury has pecuniary effects that do not affect the marginal utility of money, then the efficient choice is to purchase insurance fully covering the pecuniary effects and completely excluding the nonpecuniary effects; (3) when an injury has nonpecuniary effects that lower the marginal utility of money, then efficient insurance excludes nonpecuniary loss and covers less than full pecuniary loss; and (4) if the nonpecuniary effects of injury increase the marginal utility of money, then efficient insurance, according to some but not all theorists, ${ }^{42}$ includes some nonpecuniary loss coverage.

\section{B. Scholarly Treatment of the Theory}

Although the insurance theory has received little criticism as a compensatory guide, ${ }^{43}$ analysts differ in the manner and degree of

decrease her wealth, and thus that, in accident states, she will purchase less. Hence, even as to an injury whose nonpecuniary consequences increase the marginal utility of wealth, she will choose not to insure herself fully for that increase (because she knows that overall she will have less wealth). This version of the argument is tautological. Whether an accident decreases wealth depends in large part on how much compensation will be paid-yet the argument assumes that wealth will decrease in order to prove that less compensation should be paid.

42 Professor Schwartz, for example, argues against coverage for nonpecuniary losses in such instances. See supra text accompanying notes 37-41.

43 See supra notes 6-10 and accompanying text. The most severe criticism of the insurance theory has emerged in two recent articles that question certain common assumptions of the insurance theory literature. See Stephen P. Croley \& Jon D. Hanson, What Liability Crisis? An Alternative Explanation for Recent Events in Products Liability, 8 Yale J. on Reg. 1 (1991); Hanson \& Logue, supra note 22. The articles criticize the assumption that the nonpecuniary aspects of an injury generally do not increase the marginal utility of money and instead contend that the marginal utility issue is currently an unsettled empirical question. See Croley \& Hanson, supra, at 60; Hanson \& Logue, supra note 22, at 183-84 \& n.205. Hanson \& Logue also take issue with Professor Schwartz's argument that individuals would not insure fully for nonpecuniary losses even when those losses increase the marginal utility of money. See id. at 184-86. (For my response to Professor Schwartz's argument, see supra note 41.) Croley \& Hanson assert that consumer demand arguably does exist for nonpecuniary loss insurance, but that various market impediments prevent an adequate supply of that good. See Croley \& Hanson, supra, at 61-67. In fact, they argue that rather than equalizing marginal utility as the insurance theory claims, consumers might aim to equalize total utility across different states of the world. The latter aim would support compensation beyond the pecuniary level. See id. at 60 n.201.

Several other articles have criticized aspects of the insurance theory, but these criticisms do not seem intended to question at a fundamental level the theory's usefulness from a compensatory perspective. For example, Professor Rubinfeld has set out some concerns about 
their endorsements. ${ }^{44}$ Nonetheless, for several reasons, it is fair to treat the insurance theory as a set of proposed guidelines for determining the compensatory measure in many programmatic settings. First, the theory has been explicitly endorsed as a guide to compensation in a major injury area-products injuries. ${ }^{45}$ Second, although the literature frequently points out the need to address deterrence concerns via some fine, surcharge, or modification of the compensatoryinsurance measure, ${ }^{46}$ even such proposals would make use of the insurance theory to set the compensatory level of compensation. ${ }^{47}$ Third, some analysts view the insurance theory as the proper approach for programs-such as the tort system - that rest largely on an insurance rationale or function largely as insurance programs. For example, Professor Danzon argues that the theory offers an appropriate critique of the tort system because that system "provides compul-

the deterrence implications of using the insurance theory. See Daniel L. Rubinfeld, On Determining the Optimal Magnitude and Length of Liability in Torts, $13 \mathrm{~J}$. Legal Stud. 551 (1984); see also Neil K. Komesar, Injuries and Institutions: Tort Reform, Tort Theory, and Beyond, 65 N.Y.U. L. Rev. 23, 57-59 (1990) (discussing deterrence concerns raised by the insurance theory). Professor Rubinfeld notes some possible problems with relying on the mechanism of a deterrence "surcharge"-a mechanism that has been advocated as a means of providing the deterrence force that the insurance theory lacks. Rubinfeld, supra, at 553-55. In a similar vein, the ALI Reporters' Study raises a number of questions about the administrative feasibility of a tort fine or surcharge. See 2 ALI Reporters' Study, supra note 10, at 213-16. These criticisms are concerned with how deterrence aims will be addressed in a program that relies on the insurance theory for purposes of compensation. My critique is directed to the theory's fundamental shortcomings from a compensatory perspective; I do not take up the deterrence implications because I believe that the theory deserves rejection even from a purely compensatory perspective.

44 Professor Schwartz, for example, explicitly argues that the insurance theory should be the basis for determining the types and amounts of compensation payable for product-related injuries. Schwartz, supra note 9, at 362-67. The ALI Reporters' Study seems sympathetic to the theory, but does not embrace all of its implications. See supra note 10 . Virtually all analysts view the theory as embodying efficient or optimal compensation in the economist's sense of these terms, see, e.g., Shavell, supra note 6, at 228-30, 231 n.2; Arlen, supra note 25, at 73 , but do not necessarily argue that an efficiency goal alone should animate accident or compensation law. See, e.g., Shavell, supra note 6, at 296; Danzon, Medical Malpractice, supra note 8 , at 10 .

45 See Schwartz, supra note 9, at 362-67; Viscusi, Reforming Products Liablity, supra note 7 , at $87-94$.

46 See supra notes 17 and 43 .

47 This would not be the case if one's concern about inadequate deterrence led one to reject an "insurance amount plus deterrence fine" approach and, thus, any use of the insurance theory. Cf. Rubinfeld, supra note 43, at 553-55 (raising concerns about the use of a deterrence surcharge). 
sory insurance."48 Because future and most existing nontort programs (such as social security disability or workers' compensation) arguably will or do function primarily as insurance programs, those willing to apply the insurance theory to the tort system almost surely will find it applicable to nontort structures. Fourth, the view that the insurance theory provides efficient compensation ${ }^{49}$ forms the basis of a normative case that many may find persuasive. Many analysts already believe that efficiency considerations should serve as the primary basis for the selection of legal rules. ${ }^{50}$ The insurance theory will undoubtedly be persuasive to such efficiency proponents, as long as its claim of efficiency seems warranted and its maxims appear to be determinate, coherent, and workable. There is no suggestion in the literature that the insurance theory lacks these qualities; at most, some commentators acknowledge a few empirical gaps that presumably can be addressed by further study. ${ }^{51}$

The two most important features of the insurance theory are the question of marginal utility in relation to specific losses and the distinction between pecuniary and nonpecuniary losses. The latter feature represents the categorization that is central to the theory's compensatory decisions; the former determines whether compensation will be the same, more, or less than pecuniary loss. The next two Parts of the Article expose the failings of these critical elements of the theory.

48 Danzon, Tort Reform, supra note 8, at 520. The ALI Reporters' Study also seems to take this approach, at least in part. It argues that tort law largely has become a "port of entry into an insurance program paid for and provided by members of the community for themselves." 2 ALI Reporters' Study, supra note 10, at 206. Given this characterization, "the claim of pain and suffering to any, let alone full, compensation appears shaky." Id. For this conclusion, the study cites the insurance theory literature. Id. at $206 \mathrm{n}$.13. Yet, the study goes on to provide arguments for some payments compensating nonpecuniary loss. See supra note 10 .

49 See Shavell, supra note 6, at 228-30, 231 n.2; Arlen, supra note 25, at 73.

50 See, e.g., A. Mitchell Polinsky, An Introduction to Law and Economics 124-26 (2d ed. 1989); Richard A. Posner, The Ethical and Political Basis of the Efficiency Norm in Common Law Adjudication, 8 Hofstra L. Rev. 487 (1980).

${ }^{51}$ See, e.g., Arlen, supra note 25 , at 73 n.149 (noting need for more empirical analysis of the marginal utility point). 


\section{The Marginal Utility Query: Judgments About DISABILITY AND THE COSTS OF ERROR}

One of the insurance theory's central features is the need to determine how nonpecuniary dimensions of an injury affect the marginal utility of money. Three possibilities exist: if injury does not affect the marginal utility of money, then optimal insurance covers full pecuniary loss; if the marginal utility of money increases after injury, optimal insurance may cover more than pecuniary loss; ${ }^{52}$ and if the marginal utility of money declines after injury, then optimal insurance will cover less than full pecuniary loss. ${ }^{53}$ To guide decisions about optimal compensation, then, the insurance theorist must be able to derive and apply some defensible conclusion about the marginal utility variable. This condition, however, cannot be satisfied.

Stated briefly, the following sections will show that the marginal utility query currently remains unanswered (despite assertions in the literature to the contrary), that the perspective of the nondisabled is an unacceptable basis for any marginal utility conclusion, and that reliance on the perspective of the disabled is indefensible because of the extent to which that perspective is shaped by discriminatory social attitudes and structures. Finally, this Part demonstrates that the marginal utility query poses severe implementation problems.

\section{A. Existing Data and the Problems with the Nondisabled Perspective}

It hardly needs saying that the disabled, individually and as a group, contravene all the values of youth, virility, activity, and physical beauty that Americans cherish, however little most individuals may realize them. ... And to the extent that we depart from the ideal, we become ugly and repulsive to the able-bodied. People recoil from us, especially when there is facial damage or bodily distortion. The disabled serve as constant, visible reminders to the able-bodied that the society they live in is shot through with inequity and suffering, that they live in a counterfeit paradise, that they too are vulnerable. We represent a fearsome possibility.

-Robert Murphy ${ }^{54}$

\footnotetext{
52 As previously explained, some of the literature disputes even this point. See supra notes 37-41 and accompanying text.

53 See supra text accompanying note 33 .

54 Murphy, supra note 13, at 116-17.
} 
Insurance theorists frequently conclude that the marginal utility of money generally declines postinjury. ${ }^{55}$ For example, the economist and analyst W. Kip Viscusi states: "It is usually assumed that for any particular expenditure level, a health impairment reduces the incremental increase in welfare of further expenditures."56 A report of a recent study coauthored by Professor Viscusi purports to provide empirical proof that the marginal utility of money declines postinjury $^{57}$ and has already been cited for that point in the literature. ${ }^{58}$ These assumptions and conclusions all have fatal shortcomings. ${ }^{59}$

55 See, e.g., Schwartz, supra note 9, at 364-66; see also supra notes 36-39 and accompanying text (discussing Schwartz's argument). Professor Viscusi's position is discussed infra notes 5658 and accompanying text. In addition to the arguments of Professors Schwartz and Viscusi, see Bovbjerg et al., supra note 3, at $932 \&$ n.130 (noting empirical evidence that supports the conclusion that poor health decreases marginal utility and commenting that it may remain "hypothetically plausible" that "some injuries" increase the marginal utility of money); David Friedman, What is 'Fair Compensation' for Death or Injury?, 2 Int'l Rev. L. \& Econ. 81, 8283 (1982) (outlining theoretical argument that purportedly demonstrates postinjury declines in the marginal utility of money); cf. George L. Priest, Modern Tort Law and Its Reform, 22 Val. U. L. Rev. 1, 16 (1987) (stating that "pain and suffering losses do not affect the marginal value of wealth"); Priest, supra note 20, at 1553 (stating that "[n]on-pecuniary losses do not affect the marginal value of wealth across states of the world").

Several analysts have criticized the frequent assumption that marginal utility declines after an injury, taking instead the position that the empirical issue is still unclear. See Arlen, supra note 25, at $73 \mathrm{n} .149$; Croley \& Hanson, supra note 43, at 60; Hanson \& Logue, supra note 22, at 183 \& n.205; Rubinfeld, supra note 43 , at 553 n.5.

56 W. Kip Viscusi, Risk By Choice 89 (1983).

57 See Viscusi \& Evans, supra note 7.

58 See 2 ALI Reporters' Study, supra note 10, at 206 n.13; Bovbjerg et al., supra note 3, at $932 \&$ n. 130 .

59 Viscusi \& Evans, supra note 7, is the only attempt, thus far, to document the point empirically; I address their study in the text. See infra text accompanying notes 60-93. The mere assumption of declining marginal utility is not defensible. Although Danzon appears to argue that existing patterns of social and private insurance serve as some empirical evidence on the marginal utility point, see Danzon, Tort Reform, supra note 8 , at 522-26, this argument seems unacceptable for a number of reasons. See infra text accompanying notes 143-44; Arlen, supra note 25 , at $73-74 \& \mathrm{n} .149$ (arguing that existing insurance patterns do not lead to a firm conclusion on the marginal utility issue).

Economist David Friedman also argues that injured persons generally receive less value from each dollar. See Friedman, supra note 55, at 82 . His argument proceeds in the following way. Suppose that an injured person receives full compensation for his pecuniary losses, so that he can afford to consume the same things after injury that he could before. "Since he is no longer able to consume some of those things (color television if he has been blinded), he spends what previously went for goods he can no longer use on the remaining sorts of consumption," such as "gourmet dinners." Id. at 82 . But, before injury, the last dollar spent on a color television provided the same benefit as the last dollar spent on gourmet dinners; if not, the individual would have purchased more of one and less of the other. Hence, after injury, "he must transfer the money he previously would have spent buying a television to buying more 
The most rigorous attempt thus far to address the marginal utility point is the empirical study reported by Professors Viscusi and William Evans in the June 1990 issue of the American Economic Review. ${ }^{60}$ The study made use of data obtained from an earlier study

(and increasingly less pleasurable) gourmet dinners." Id. On this basis, Friedman concludes that the benefit an injured person receives from each marginal dollar is less after injury. Id.

To the extent that Professor Friedman intends this anecdote to prove any general marginal utility conclusion, it is unsuccessful in doing so. The argument assumes, unrealistically, that an injured person is basically choosing among the same consumption options as before. In fact, an injured person will be considering consumption options (such as adaptive technology, vocational training, alternative methods of recreation and social interaction) that, although theoretically available before injury, do not form part of the spectrum of consumption options considered by noninjured persons. In addition, Friedman does not take account of the likelihood that serious injury will prove to be a transformative experience. See infra text accompanying notes 84-87.

60 Viscusi \& Evans, supra note 7. Although the efforts of Viscusi and Evans represent the first empirical study directed specifically to the marginal utility query, a fair amount of data exists regarding an analogous topic: the "quality of life" in various health states. In recent years, the concept of "quality-adjusted life-years" (QALYs) has played a significant role in the vigorous debate over health-care allocation and rationing. As one commentator explains, the QALY "is an index designed to take account of the quality as well as the duration of survival in assessing the outcome of health-care procedures or services." Alwyn Smith, Qualms About QALYs, 1 Lancet 1134, 1134 (1987). There is considerable debate about the use of QALYs, both at the macro-allocation level and the individualized patient level. See, e.g., Jerry Avorn, Benefit and Cost Analysis in Geriatric Care, 310 New Eng. J. Med. 1294, 1298-99 (1984); John La Puma \& Edward F. Lawlor, Quality-Adjusted Life-Years: Ethical Implications for Physicians and Policymakers, 263 JAMA 2917, 2917-21 (1990).

QALYs obviously involve an inquiry different from that of marginal utility. Yet, some overlap exists, because postinjury quality of life plays a role in the postinjury marginal utility of wealth. It is worth noting, then, that a number of studies have been aimed at devising and applying various quality of life measures. Some discussion has even been directed at a question analogous to the one raised in this text: on whose perspectives should studies of quality of life focus-the noninjured, the injured, or others? See, e.g., Paul T. Menzel, Strong Medicine: The Ethical Rationing of Health Care 89-91 (1990) (arguing that such studies should focus in large part on judgments by those who experience the states of ill health that are the subject of the inquiries); Gillian Capewell, Techniques of Health Status Measurement Using a Health Index, in Measuring Health: A Practical Approach 45, 51-52 (George T. Smith ed., 1988) (discussing whose perspectives are appropriate in various types of health inquiries); E. Haavi Morreim, Computing the Quality of Life, in The Price of Health 45, 61 (George J. Agich \& Charles E. Begley eds., 1986) (arguing that, in quality of life assessment, it is improper to "ignore[ ] entirely the crucial difference of perspective between those who suffer a particular malady and those who do not").

Interestingly, the QALY studies suggest that there may be differences in the opinions of the healthy and unhealthy concerning the quality of life in various health states. See Rachel Rosser, A History of the Development of Health Indicators, in Measuring the Social Benefits of Medicine 50, 57 (George T. Smith ed., 1983) (describing study in which raters gave different assessments depending on the rater's experience of illness with medical patients putting less emphasis on severe states of ill health than did healthy volunteers). Contra Capewell, supra, at 
of chemical workers, ${ }^{61}$ in which the workers were asked to state the wage increase that would be necessary to compensate them for exposure to an additional level of risk. From this "reservation wage" data (along with other data), Professors Viscusi and Evans extracted a conclusion about the workers' implicit assessment as to whether the marginal utility of money would increase, decline, or remain constant if the risk materialized and they were injured. ${ }^{62}$ The study concluded that the workers' responses revealed an implicit conclusion that the marginal utility of money after injury would be about one-fourth less than it was before. ${ }^{63}$

Professors Viscusi and Evans conclude that the study provides empirical proof that "the marginal utility of a given level of income [is] greater when [the person is] healthy than when injured."64 Actually, the study at best proves something quite different and far more limited than the authors claim: that, from the perspective of the nondisabled, the marginal utility of money declines postinjury. ${ }^{65}$ And this tells us, in fact, very little that is useful for compensation purposes.

Reliance on the nondisabled perspective assumes the capacity of the nondisabled to reach informed judgments about life options in various states of disability. At least three serious obstacles make such judg-

52 (stating that "[e]merging evidence" suggests that raters' experiences with illness do not produce different assessments).

61 Viscusi \& Evans, supra note 7, at 355 \& n.4 (citing earlier study). The earlier study is reported in W. Kip Viscusi \& Charles J. O'Connor, Adaptive Responses to Chemical Labeling: Are Workers Bayesian Decision Makers?, 74 Am. Econ. Rev. 942 (1984).

62 Viscusi \& Evans, supra note 7, at 356. Each worker in the study was presented with a hazard warning label for one chemical that was not involved in his or her job and then was asked to rate the risk posed by that chemical on a linear scale ranging from very safe to very dangerous. Id. Each worker was then asked how much additional salary would be necessary to induce him or her to work with the chemical. This data provided enough information to mark two points: (1) the initial risk and each worker's existing weekly earnings; (2) the perceived increased risk and the earnings necessary to compensate for it. Id. at 357 . On the assumption that workers would attempt to equalize expected utility before and after facing an increased risk, Viscusi and Evans used various statistical methods to extract the workers' implicit conclusions about the postinjury marginal utility of money. Id. at 358-67.

63 Id. at 360.

64 Id. at 371.

65 The study reported by Viscusi and Evans might be subject to additional qualifications or criticisms. My discussion addresses only those limitations that are most relevant to my basic point: that reliance on the nondisabled perspective about postinjury quality of life or marginal utility of money is not acceptable. 
ments unlikely. ${ }^{66}$ The first is an informational problem. The nondisabled are unlikely to be any more than minimally or anecdotally knowledgeable about life options in various states of impairment, disability, or handicap. The necessary level of knowledge would include information about the functional effects of various impairments or disabilities, ${ }^{67}$ what means are available (if any) to address those limitations, ${ }^{68}$ and the whole range of postinjury activities and choices that the nondisabled rarely need to consider or select, such as adapted transportation, vocational rehabilitation, ${ }^{69}$ adapted recreation, and alternative means of social and personal interaction. ${ }^{70}$ The information about these life options is extensive, varied, and often complex or technical. ${ }^{71}$ Even those knowledgeable about certain losses-such as

66 Although all three of the obstacles, discussed infra text accompanying notes $67-87$, might be characterized broadly as informational, it is useful to separate them for purposes of discussion.

67 Gaining this knowledge alone would be a formidable challenge, given the tremendous diversity that exists in the kingdom of the ill. See U.S. Comm'n on Civil Rights, Accommodating the Spectrum of Individual Abilities 4 (1983) (noting the diversity of disability and the "remarkably heterogenous" nature of the individuals grouped under the label "handicapped"); see also infra note 103 (providing further evidence of the diversity among disabled populations).

Of course, knowledge about the diverse types of loss would be irrelevant if one plausibly could contend that the marginal utility effect of diverse losses was basically the same across the board. For example, individuals would not need to understand the differences between head injuries and respiratory impairments if both sorts of impairments affected the marginal utility of money in similar ways. But this contention is plainly untenable. See infra notes 103-04 and accompanying text.

68 Driving aids, robotics, adapted computer interfaces, telecommunications devices, and speech synthesizers are but a few examples. See Stanford E. Rubin \& Richard T. Roessler, Foundations of the Vocational Rehabilitation Process 291-304 (3rd ed. 1987) (describing technological options available to the disabled); Catherine W. Britell \& Samuel R. McFarland, Adaptive Systems and Devices for the Disabled, in Rehabilitation Medicine 372, 372-87 (Joel A. DeLisa ed., 1988) (describing various rehabilitative and adaptive devices).

69 Consider, for example, the basic evaluative steps that must be undertaken in the vocational rehabilitation process. These include (at a minimum) assessment of (1) the individual's exact functional limitations and (2) the occupational tasks and settings that are consistent with those limitations. See Rubin \& Roessler, supra note 68, at 205-22.

70 See generally Donald E. Shrey, Judith S. Kiefer \& William A. Anthony, Sexual Adjustment Counseling for Persons with Severe Disabilities: A Skill-Based Approach for Rehabilitation Professionals, in The Psychological and Social Impact of Physical Disability 233, 233-46 (Robert P. Marinelli \& Arthur E. Dell Orto eds., 2d ed. 1984) (outlining a stepby-step approach to facilitating the sexual adjustment of the severly disabled).

71 Examples include telecommunications devices for the deaf, modified computer interfaces, and myoelectric hands and other robotic devices. See Rubin \& Roessler, supra note 68, at 291314 (describing these and other technologies). 
someone close to a paraplegic-probably know little about others. Reinforcing this point is the reality addressed, but not solved, by several pieces of major federal legislation relating to disability rights: ${ }^{72}$ a powerful and varied set of socially constructed barriers exists between the "able-bodied" and disabled worlds.

The second problem with relying on the nondisabled perspective is cognitive or psychological. Even if the nondisabled generally had access to necessary information about life in various health states, adequate "knowledge" requires that they have the cognitive and psychological capacity to process that information without serious distortion. The narrative, sociological, and psychological literature relating to disability raises all sorts of doubts that such capacity commonly exists. $^{73}$

Perhaps the overriding question stems from a constant feature of our societal landscape: the devaluation of the disabled. The causeseven the possible definitions - of devaluation are many and varied, ${ }^{74}$ but its ubiquitous presence can hardly be disputed. ${ }^{75}$ One hardly

72 Before 1990, these included the Rehabilitation Act of 1973, 29 U.S.C. $\S 794$ (1988), the Education of the Handicapped Act, 20 U.S.C. $\S \S 1400-1485$ (1988), and the Architectural Barriers Act of 1968, 42 U.S.C. $\S \S ~ 4151-4157$ (1988). Yet, years after these laws were passed, the United States Commission on Civil Rights concluded that discrimination in various arenas, including employment, education, and accessibility, was still widespread. See U.S. Comm'n on Civil Rights, supra note 67, at 27-42. In recognition of that persistent discrimination, Congress passed the Americans with Disabilities Act of 1990, Pub. L. No. 101-336, 104 Stat. 328 (codified at 42 U.S.C. $\S \S 12101-12213$ (Supp. 1991)). See 42 U.S.C. $\S 12101$ (a) (stating congressional findings relating to extensive and significant discrimination against the disabled).

73 The points discussed herein draw from more general discussions of how the disabled view or process information about disability. See Robert Murphy, supra note 13; Constantina Safilios-Rothschild, The Sociology and Social Psychology of Disability and Rehabilitation 10930 (1970); U.S. Comm'n on Civil Rights, supra note 67; Beatrice A. Wright, Physical Disability-A Psychosocial Approach 31-94 (2d ed. 1983); Gloria Ladieu-Leviton, Dan L. Adler \& Tamara Dembo, Studies in Adjustment to Visible Injuries: Social Acceptance of the Injured, in The Psychological and Social Impact of Physical Disability, supra note 70, at 148; Hanoch Livneh, On the Origins of Negative Attitudes toward People with Disabilities, in The Psychological and Social Impact of Physical Disability, supra note 70, at 167.

74 For example, the U.S. Commission on Civil Rights concluded that four major sources of prejudicial attitudes toward the disabled are discomfort, patronization, stereotyping, and stigmatization. See U.S. Comm'n on Civil Rights, supra note 67, at 22-27. See generally Livneh, supra note 73 , at $167-84$ (describing various sources of negative attitudes toward the disabled and summarizing relevant literature).

75 One need not accept particular theories about why devaluation occurs to conclude that the phenomenon is extensive. For general discussions regarding devaluation of and prejudice against the disabled, see Murphy, supra note 13, at 112-36; U.S. Comm'n on Civil Rights, supra note 67, at 17-45; Carolyn L. Vash, The Psychology of Disability xvi-xix (1981); Daniel 
needs unanimity about the causes or exact extent of devaluation to conclude that devaluative forces-of our own or others' makingplay a powerful role in shaping our attitudes about the nature and quality of disabled life.

For example, in her classic text on disability, Beatrice Wright drew on both empirical and narrative sources to explain the phenomenon of "spread"- that is, the tendency of the nondisabled to draw inferences about other qualities of the disabled person from some single facet of disability. ${ }^{76}$ An example is the story recounted by a blind person, Karsten Ohnstad, who often went to the library accompanied by a friend. As Ohnstad explains, his exchanges with one librarian often fit the following pattern:

"What book does he want?" she would ask, looking straight at Oscar who was standing beside me.

Oscar would turn to me. "What book did you say you wanted?" "Les Miserables by Hugo."

Oscar would turn back to the librarian. "He wants Les Miserables by Hugo."

The librarian got the book. "Does he want to take it with him?" "Do you want to take it with you?"

"Yes, I want to take it with me."77

As Wright theorized, the nondisabled "generalize from the physical characteristic because to them this represents a crucial deviation that affects a person in ways they presume to understand."78 Wright explained that, "[b]ecause of spread, the degree of disability is often perceived as more severe than it actually is." 79

Wright also noted a point that appears throughout the disability literature: the nondisabled frequently overlook the importance of the many social and environmental factors that create or exacerbate handicapping conditions. ${ }^{80}$ This strengthens the tendency to suppose that a disability or handicap is something that is endemic to and inevi-

W. Cook, Impact of Disability on the Individual, in Rehabilitation Counseling 143, 154-57 (Randall M. Parker \& Carl E. Hansen eds., 1981) (describing studies showing relatively general patterns of rejection and devaluation by the nondisabled toward the disabled).

76 See Wright, supra note 73 , at 32-39.

77 Id. at 35 (quoting Ohnstad). Similar examples appear throughout the literature.

78 Id. at 33 .

79 Id.

80 See id. at $45-47$. 
tably flows from an injury. ${ }^{81}$ To the extent this assumption occurs, the severity and permanence of the effects of various injuries will be overestimated. These common distortions are just some among many that raise questions about the cognitive and psychological capacity of the nondisabled to form meaningful judgments about various health states. ${ }^{82}$ To be sure, in part these cognitive distortions are themselves products of inadequate information about various states of impairment, disability, and handicap. Could one plausibly argue, then, that improvements in information could justify reliance on the nondisabled perspective? This is unlikely to be the case, ${ }^{83}$ but one need not be convinced of the point to reject the insurance theory's reliance on the nondisabled perspective.

This is so because the nondisabled face a third impediment in forming conclusions about the nature and quality of life in disability states: the experience of permanent loss may transform the individual in a way that will render obsolete even fully informed pre-injury judgments about the quality and nature of postinjury life. The narrative, sociological, and psychological literature of disability makes clear that loss often forces reexamination, reconceptualization, and the alteration of values, attitudes, beliefs, and desires. ${ }^{84}$ As the anthropologist Robert Murphy explains his own experience of permanent paralysis:

Disablement is at one and the same time a condition of the body and an aspect of social identity-a process set in motion by somatic

81 Id. at 46 (" $[\mathrm{T}]$ he consequences of underrating the significance of environmental factors in causal attribution are severe, for it hinders the realization that circumstances can enormously increase or reduce the extent of a handicap.").

${ }^{82}$ For other discussions relating to the attitudes and perspectives of the nondisabled toward the disabled, see id. at 52-77; sources cited supra notes 74-75.

${ }^{83}$ Some researchers have investigated the ability to alter attitudes toward the disabled. Their work suggests that the most powerful strategy for changing attitudes is to combine increased information about disability with increased contact with the disabled. See William A. Anthony, Societal Rehabilitation: Changing Society's Attitudes toward the Physically and Mentally Disabled, in The Psychological and Social Impact of Disability, supra note 70, at 193, 193-203; Cook, supra note 75, at 160. Given the still-substantial invisibility of the disabled in our society, however, the conditions necessary for implementing this strategy seem unlikely to exist at any point in the foreseeable future.

84 See Murphy, supra note 13, at 85-111, 195-231 (describing in detail the many transformative effects of the author's serious disability); Vash, supra note 75, at 124-38 (describing the process of change and transcendence during a lifetime of disability); Marilynn J. Phillips, Disability and Ethnicity in Conflict: A Study in Transformation, in Women with Disabilities 195, 196-200 (Michelle Fine \& Adrienne Asch eds., 1988) (discussing a number of theories of transformation that have appeared in the literature). 
causes but given definition and meaning by society. It is preeminently a social state. And so it was that as my upper body functions became atrophied under the pressure of the growing spinal cord tumor, my social orbit shifted, my horizons shrank, my conduct of life became altered, and my sense of self underwent further deep transformation. ${ }^{85}$

Such stories of transformation abound in the disability literature. As one individual described the impact of disability:

When I did [accept my disability], it wasn't at all like [I had] envisioned; settling for second-rate goals and dreams. It wasn't even defusing the disappointment that I would never again hear whistles when I walked, or dance, or ride in a horse show, or walk alone in the rain, or go to the bathroom by myself. It sure as hell wasn't the much touted process of discovering substitute gratifications for the ones I had lost.

It was more like those things not only didn't matter any more, they wouldn't have mattered even if I could still have done them. I didn't need to be able to do them-or to mourn their loss-in order to maintain some image of myself. ${ }^{86}$

These passages, and the vast literature of which they are a part, cast doubt on the assumption that an individual's preferences generally remain unaltered after certain injury or disease experiences. ${ }^{87}$ To be sure, the exact shape and strength of that doubt could vary. ${ }^{88}$ Under

85 Murphy, supra note 13, at 195.

86 Vash, supra note 75, at 137 (second alteration in original) (quoting from an interview).

87 This conclusion does not depend on any particular theory of how or why transformation occurs; these are issues on which there is no consensus in the literature. See Phillips, supra note 84, at 196-200 (discussing various theories of transformation that have appeared in the literature).

${ }^{88}$ I am not aware of any literature that explores the implications of how disability may alter individual preferences in the compensation context. This Article cannot address all of these implications, and I have yet to answer for myself many of the questions posed. Yet, one related strain of literature that might be helpful at this juncture comes to mind: the debate over whether it is proper to rely on treatment preferences expressed by a competent individual who is incompetent at the time the treatment decision must be made. Compare Norman L. Cantor, Prospective Autonomy: On the Limits of Shaping One's Postcompetence Medical Fate, $8 \mathrm{~J}$. Contemp. Health L. \& Pol'y 13 (1992) (arguing that it is morally and legally acceptable to give effect to advance directives deliberately constructed by a formerly competent person) with Rebecca S. Dresser \& John A. Robertson, Quality of Life and Non-Treatment Decisions for Incompetent Patients: A Critique of the Orthodox Approach, 17 L. Med. \& Health Care 234, 236-37 (1989) (arguing, among other things, that expressed or inferred prior choices are not an appropriate indicator of an incompetent person's current interests). Professors Dresser and Robertson argue that "[i]t is difficult, if not impossible, for competent individuals to predict 
the strongest version, one might conclude that some or many disability experiences are so transformative as to invalidate in most disability contexts any analyses or justifications that use comparisons of preferences or utilities across time. ${ }^{89}$ Alternatively, one might conclude that such analysis remains generally appropriate in disability settings, but that we need to obtain richer information about the formation and alteration of preferences, modifying our theories accordingly. ${ }^{90}$

Even those who would disagree on these fascinating, larger questions would probably agree that the transformative potential of disability has at least this implication: even a fully informed, nondevaluative pre-injury judgment is a questionable basis for conclusions about the nature and quality of postinjury life, at least as to many types of injuries and diseases. ${ }^{91}$ Thus, any real-world application of the insurance theory would be subject to severe criticism to the extent it relied on such judgments.

Taken together, these shortcomings of the nondisabled perspective-lack of information, devaluation, and the inability to envision one's postinjury self-are troublesome not simply because they impair the accuracy of marginal utility judgments. In addition, it seems plausible to conclude that in general these shortcomings will result in underestimates of postinjury marginal utility. Although one can devise scenarios in the opposite direction (e.g., lack of information

their interests in future treatment situations when they are incompetent because their needs and interests will have so radically changed." Id. at 236. Others acknowledge that radical change takes place, but nonetheless argue that advance directives are the best available means of respecting the right of self-determination. See, e.g., Cantor, supra, at 20.

${ }^{89}$ A strong proponent of the "antipreference" case might contend that transformation is so substantial that it renders impossible any intrapersonal utility comparisons across states of disability. Such a proponent would reject the insurance theory's use of marginal utility comparisons, whether the comparisons were performed by the nondisabled or the disabled. As will become clear after Part II.B, infra, I also reject the theory's use of marginal utility calculations (whether performed by the nondisabled or disabled), but not solely for the same reasons as the strong antipreference proponent.

90 For example, one might argue that we should supplement the views of the nondisabled with the views of the disabled or even that we should rely primarily on the views of the disabled in implementing the marginal utility aspect of the insurance theory. As detailed infra Part II.B, even these approaches do not dispel the practical and normative concerns raised by the insurance theory.

91 As is implicit in this statement, I think that my case against the insurance theory should persuade even those who otherwise disagree about the validity of intrapersonal utility comparisons (either generally or with respect to states of disability). That is, for the reasons outlined in Part II, even those who think such comparisons can be meaningfully performed should be troubled by the way in which the insurance theory makes use of such comparisons. 
about the devastating effects of a head injury might lead to an overestimate of postinjury marginal utility), the potential for error probably cuts in the direction of underestimation. Indeed, the study reported by Viscusi and Evans provides some support for this prediction.

To the extent this generality applies, the costs of error under the insurance theory of compensation directly and fundamentally disadvantage the injured in a context in which little room for error is tolerable. As discussed in Part I, the insurance theory calls for compensation to be reduced in accordance with any finding of declining marginal utility. Yet, the empirical and narrative literature relating to disability emphasizes the centrality of money to a disabled lifestyle. According to a recent report to Congress concerning the impact and extent of injury in the United States:

Money is central to the well-being of the injured person and family. The cost of severe injury goes far beyond initial medical treatment and includes housing, disability-related equipment, long-term rehabilitation, education, and vocational training. . . . It is realistic to be continually fearful of the cost of potential medical complications, follow-up surgical procedures, and future rehabilitation, housing, education, or job-training requirements. Needs do not stop with medical stabilization; they continue for years or for a lifetime.

A severe injury renders individual access to medical and social services, work, and housing questionable. ${ }^{92}$

As one disability counselor put it, "[t]he main problem with being disabled is being poor."93

In sum, the insurance theory's reliance on the nondisabled perspective in reaching conclusions about postinjury marginal utility is indefensible, given the shortcomings of the nondisabled perspective and their devastating real-world effects.

92 Dorothy P. Rice, Ellen J. MacKenzie \& Assocs., Cost of Injury in the United States: A Report to Congress xlii (1989) [hereinafter Cost of Injury] (emphasis omitted). This report, prepared pursuant to congressional mandate, was the third in a series of reports to Congress on the extent of injury in the United States. Id. at v-vi. The research was conducted by the Institute for Health \& Aging, University of California, San Francisco, and by the Injury Prevention Center, School of Hygiene and Public Health, The Johns Hopkins University. Id. at vi.

93 Vash, supra note 75 , at 33 (quoting disability counselor). 


\section{B. Future Research Efforts: Relying on the Disabled Perspective}

Whatever the physically impaired person may think of himself, he is attributed a negative identity by society, and much of his social life is a struggle against this imposed image. It is for this reason that we can say that stigmatization is less a by-product of disability than its substance. The greatest impediment to a person's taking full part in his society are not his physical flaws, but rather the tissue of myths, fears, and misunderstandings that society attaches to them.

-Robert Murphy ${ }^{94}$

Proponents of the insurance theory might argue that, even if the use of the nondisabled perspective is inappropriate, the theory can nonetheless address the marginal utility query in a defensible way: empirical studies could examine various health states not from the perspective of the noninjured, but from the perspectives of the impaired, disabled, and handicapped. The results of such research then could be incorporated within various decisional structures that compensation programs might employ.

This response, however, has a critical failing. Despite a number of federal and state laws aimed at combating disability discrimination and enhancing the integration of the disabled into mainstream society, the disabled continue to face numerous unjustifiable obstacles in employment, transportation, housing, and social interaction. ${ }^{95}$ As the

94 Murphy, supra note 13 , at 113 .

95 In passing the Americans with Disabilities Act of 1990, Pub. L. No. 101-336, 104 Stat. 328 (codified at 42 U.S.C. $\S \S 12101-12213$ (Supp. 1991)), Congress expressed several findings relating to the still-extensive levels of disability discrimination. These include findings that (1) despite some improvements, discrimination is still a "serious and pervasive social problem," id. $\S 12101(\mathrm{a})(2)$, and (2) discrimination persists in "such critical areas as employment, housing, public accommodations, education, transportation, communication, recreation, institutionalization, health services, voting, and access to public services," id. $\S 12101(\mathrm{a})(3)$. For more detail about the types and impacts of disability discrimination, see Frank Bowe, Handicapping America: Barriers to Disabled People 18-39, 73-106, 134-84 (1978) (discussing barriers in employment, education, transportation, and building accessibility); Murphy, supra note 13, at 112-61 (describing attitudinal and social barriers faced by the disabled); U.S. Comm'n on Civil Rights, supra note 67, at 27-42 (summarizing types and extent of discrimination against the disabled in transportation, education, employment, and other spheres); Jim L. Daniels, World of Work and Disabling Conditions, in Rehabilitation Counseling, supra note 75 , at 169, 182-86 (describing work-related barriers faced by the disabled); David D. Stock \& Jean A. Cole, Adaptive Housing for the Severely Physically Handicapped, in The Rehabilitation Client 205, 206-08 (Brian Bolton \& Marceline E. Jaques eds., 1979) (reviewing obstacles to accessible and independent housing for the disabled). 
United States Commission on Civil Rights concluded (years after the enactment of major federal disability rights legislation): ${ }^{96}$ "Impairments in physical and mental abilities undeniably exist, but the degree to which they control a person's participation in society is as much inherent in the social context as in the impairment."97 Similarly, "[a]uthorities from every branch of government have concluded ... that prejudice and discrimination are major causes of the disadvantages confronting handicapped people."98

These realities inevitably would affect a disabled person's judgments about the nature of postinjury life, including assessments of marginal utility. ${ }^{99}$ For example, a disabled person might conclude that money has been less valuable after injury, at least in part because she has faced social and attitudinal barriers that have diminished the uses of her money and the satisfaction she can garner from those uses. In addition, she could reach this diminished marginal utility conclusion even though money, postinjury, is still quite valuable to her.

Scenarios such as these are not aberrations. Discrimination and devaluation will continue to make their presence known in the lives of the disabled, and these forces will often and perhaps even generally tend to reduce estimates of postinjury marginal utility. One must appreciate, then, how the insurance theory would respond to this scenario and others like it: even if discriminatory forces are the reason why marginal utility has declined, and even if money is still valuable to the disabled individual, compensation will be reduced to a level even below pecuniary loss.

This result undermines any normative force that the theory otherwise could claim. As will be detailed later, the normative case for the theory must rely heavily on the notion that the theory incorporates people's actual or likely preferences and thus promotes values such as autonomy or utility-maximization. ${ }^{100}$ This premise fails utterly if our evidence of preferences is a set of disability-related judgments that are

96 The Commission's report, supra note 67, was published in 1983; various pieces of federal disability rights legislation were enacted in the 1970s. See supra note 72 .

97 U.S. Comm'n on Civil Rights, supra note 67, at 89.

98 Id. at 17.

99 See supra text accompanying note 97.

100 See infra text accompanying notes 149-59. 
themselves the product of a social order that is unjustifiably hostile and nonaccommodating to the disabled. ${ }^{101}$

In sum, it seems no more defensible to rest a conclusion about marginal utility on the perspectives of the disabled than to rest it on the perspectives of the able-bodied. To this conclusion, an insurance theorist might reply that any compensation program eventually must arrive at loss-related judgments-about the degree of loss, the consequences of that loss, and the degree of compensation that is appropriate-and inevitably must draw on some perspective or set of perspectives in reaching those judgments. There may be biases in whatever perspective is ultimately chosen, but no system can avoid choosing one altogether. Thus, one might argue, it is unfair to single out the insurance theory for criticism on this basis.

At a general level this response has a point: the complexity of the world of injury, as well as the questions of whose perspectives should count and how to count them, are issues with which any theory must cope. They are not the creation of the insurance theory. But the ways in which the insurance theory addresses those issues lead to flaws that are specific to or especially forceful in the context of that theory. The theory gives a determinative role to a particular variable - the postinjury marginal utility of money - that is inevitably affected by devaluative assumptions about disability and discriminatory social realities. Yet the theory offers no means of filtering out or adjusting for these devaluative influences. Even more troubling, the theory exacerbates the impact of devaluation and discrimination because it generally or quite often will reduce compensation as a result of how those realities affect the marginal utility calculation. Finally, the adjustments that result from the marginal utility calculation are applied to a level of

101 The insurance theorist might argue that the existence of discrimination, although unfortunate, is not pertinent to the insurance theory at this juncture. After all, the theorist might reply, the disabled individual's appraisal of postinjury marginal utility is "accurate," even if it is partly the product of discrimination. Why, then, force an individual to part with funds at a time when they are more valuable (pre-injury) in order to have money at a time when it is less valuable (postinjury)?

If we were talking solely about private first-party insurance purchases, or about the way that an individual might "self-insure" against injury by a personal savings plan, simply taking discrimination as a given would not be so troublesome. But the proponents of insurance theory advocate its use as a guide in contexts other than these, when there is no practical or normative justification for beginning and ending with disability-related preferences that often reflect the influence of discrimination. 


\author{
compensation (pecuniary loss alone) that leaves little cushion for \\ error. ${ }^{102}$
}

\title{
C. The Marginal Utility Variable: Implementation Problems
}

A program guided by the insurance theory must, of course, implement its marginal utility variable in some way-by means of a generalized marginal utility conclusion, a schedule of such conclusions, or case-by-case findings. Deciding among these three approaches requires some tradeoffs between accuracy and cost. Because some tradeoffs inevitably follow from the implementation of any compensation criterion, the insurance theory cannot be criticized simply because it requires such tradeoffs. Yet there are special reasons to doubt the acceptability of the tradeoffs that the marginal utility variable would require.

First, one can hardly defend the use of a generalized marginal utility conclusion: the world of loss is tremendously diverse, ${ }^{103}$ and even those who suffer from similar injuries react to disability according to a host of highly individualized factors, such as time of onset, gender,

102 By contrast, one could envision a compensation approach that largely replaced lost wages and then used a "rehabilitated self" standard for guiding determinations about the medical, rehabilitative, and nonpecuniary dimensions of loss. This approach might articulate those functions, abilitites, and activities that are deemed basic to a meaningful quality of life and then resolve issues of compensability in light of these judgments. The judgments necessary for such an approach would not be uncontroversial, and the question of whose perspectives should count would not be easily resolved. But the approach would not begin and end-as the insurance theory does-with disability-related judgments that draw from and reinforce the existing social landscape relating to a life of disability.

103 "The people commonly described as handicapped are an extremely diverse group. . . It is difficult to identify any distinguishing characteristic or unifying trait in this remarkably heterogenous group . ..." U.S. Comm'n on Civil Rights, supra note 67, at 4. Even if the world of loss is viewed only through the relatively narrow lens of "impairment"-i.e., organ or person-level functional consequence-one sees an enormous range. For example, the American Medical Association's attempt to categorize and rate permanent impairments consists of more than two hundred pages and contains twelve chapters (each devoted to a separate bodily system). See American Med. Ass'n, Guides to the Evaluation of Permanent Impairment iii-v (Alan L. Engelberg ed., 3d ed. 1988) (table of contents). This diversity would be immaterial to marginal utility arguments if one could defensibly posit that the marginal utility effects of diverse losses are generally the same across the board. That position is, however, implausible. Frank Bowe, an advocate for the disabled, sets out brief "day in the life" accounts relating to various impairments, such as deafness, blindness, paraplegia, and mental disorders. See Bowe, supra note 95, at 46-69. It would be difficult to read even these brief accounts of only several types of impairments and contend that the marginal utility effects of different losses are generally similar. 
pre-injury interests and values, personality and temperament, spiritual and philosophical beliefs, wealth, and environmental factors relating to disability. ${ }^{104}$ Case-by-case determinations seem an unlikely option from both cost and efficiency perspectives. A program employing the insurance theory would not likely use such an approach, given that its potential breadth and subjectivity contradict the general tenor of the debate about compensation reform and one of its key themes-the need to reduce the administrative costs and unpredictability of the tort system. ${ }^{105}$

Some sort of schedule thus seems the only likely approach to implementing the marginal utility variable. Yet, scheduling this variable also raises several problems. First, the marginal utility variable would be particularly difficult to schedule in a way that promised even a

104 See Bowe, supra note 95, at 42 (noting the effects of education and social networking on one's adjustment to disability); Vash, supra note 75, at 9-20 (describing the many factors that can influence one's reaction and adjustment to disability); Morris B. Lieberman \& Aaron Lieberman, Psychosocial Adjustment to Physical Disability, in Physical Rehabilitation: Assessment and Treatment 9, 21 (Susan B. O'Sullivan \& Thomas J. Schmitz eds., 2d ed. 1988) (same). For example, studies have shown that neither the type of disability nor its severity is a good predictor of how independent a given person will be after injury. See Charles $\mathbf{H}$. Christiansen, Richard K. Schwartz \& Karin J. Barnes, Self-Care: Evaluation and Management, in Rehabilitation Medicine, supra note 68, at 95, 111 (citing studies that support this point).

105 See, e.g., 1 ALI Reporters' Study, supra note 7, at 30 (criticizing the tort system's excessive administrative costs); James F. Blumstein, Randall R. Bovbjerg \& Frank A. Sloan, Beyond Tort Reform: Developing Better Tools for Assessing Damages for Personal Injury, 8 Yale J. on Reg. 171, 173-76 (1991) (describing the predictability and consistency shortcomings of current tort damages law); Stephen D. Sugarman, Doing Away With Tort Law, 73 Cal. L. Rev. 555, 596 (1985) (criticizing tort's high administrative costs).

Even in the unlikely event that a program did opt for an individualized approach, the approach would pose serious normative concerns. The decisionmaker would be charged with deciding how an injury has affected the marginal utility of money to a given individual. This raises the troubling specter of the government's engaging in what are, in effect, highly subjective quality of life determinations with respect to "known" rather than statistical lives. See James F. Blumstein, Rationing Medical Resources: A Constitutional, Legal, and Policy Analysis, 59 Tex. L. Rev. 1345, 1353-54 (1981) (arguing that government should avoid making medical allocation decisions with respect to identifiable rather than statistical lives); La Puma \& Lawlor, supra note 60, at 2919-20 (arguing that technique of judging quality of life years produced by various therapies is appropriate only at the macro level, in determining aggregate community preferences). We probably do not wish to entrust decisionmakers with the discretion to lower or raise compensation in individual cases on the basis of factors such as the claimant's appearance, education, optimism, values, spiritual beliefs, family structure, and wealth. The potential for undetectable or unreviewable bias is simply too high. 
rough level of accuracy. ${ }^{106}$ In part this difficulty results from the tremendous range of factors that are relevant to the postinjury marginal utility of money. Aggravating this general problem is the reality that some factors relevant to postinjury marginal utility pose special scheduling problems. The influence of pre-injury wealth is a good example. Wealth affects values, tastes, and the consumption level of most goods. ${ }^{107}$ Thus, one can expect increases in wealth to be correlated with increased education, increased consumption of many goods and services, and a greater number and variety of recreational and nonvocational pursuits. These effects of wealth undoubtedly influence a person's reaction to disabling injury, her valuation of the activities she engages in when disabled, and the level of pleasure or utility she derives from expenditures once she is disabled. ${ }^{108}$

That wealth can affect the marginal utility variable is not difficult to see; how and how often such effects occur are questions less easily answered. One could devise endless scenarios pointing in different directions. A life of advantage and wealth may have influenced the wealthier person to value appearance and social acceptance. Once disabled, she thus might receive little pleasure even from the many pursuits still available to her. Conversely, a life of advantage and wealth may have enhanced the psychological attributes that facilitate adjustment to disability (e.g., self-esteem', richness of interests). For example, many disabled individuals must hire and supervise one or more personal employees to assist in daily activities. ${ }^{109}$ Effective selection and supervision of such assistants can be crucial to the wellbeing of the disabled person: "[m]istreatment, unreliability, exploitation, defection without notice, subtle cruelties of withholding help, and countless other abuses are reported regularly about attendants for

106 It is in the nature of schedules, of course, to sacrifice some level of accuracy for other benefits. The issue of interest, then, is the nature of the tradeoff in particular contexts. See Ellen S. Pryor, Compensation and a Consequential Model of Loss, 64 Tul. L. Rev. 783, 835-38 (1990) (discussing the general nature of the tradeoffs that schedules make).

107 Goods for which demand increases as income increases are termed normal goods; those for which demand decreases as income increases, inferior goods. Robert Cooter \& Thomas Ulen, Law and Economics 28-29 (1988). It is usually thought that most goods are normal goods. See C. Edwin Baker, The Ideology of the Economic Analysis of Law, 5 Phil. \& Pub. Aff. 3, 14 (1975); Schwartz, supra note 9, at 366.

108 See Bowe, supra note 95, at 42 (noting effects of education and social network on adjustment to disability); Vash, supra note 75, at 9-20 (describing the many factors-some of which are wealth-influenced-that can influence a person's adjustment to disability).

109 See Vash, supra note 75 , at 47. 
severely disabled individuals." 110 It is plausible to suppose that preinjury wealth correlates positively with at least some of the skills and qualities (such as assertiveness) necessary for the successful selection and supervision of assistants. ${ }^{111}$

The influence of wealth, though undeniable, is extremely difficult to translate acceptably into a schedule. One option is simply to decide that no generalizations about the nature and extent of that influence are possible. The resulting omission of wealth as a factor in the schedule plainly would reduce the schedule's accuracy. Another option is to generalize about the effect of wealth; the most plausible generalization is that pre-injury wealth correlates positively with increased postinjury marginal utility. But this would result in more significant compensation reductions as one moved down the spectrum of wealth, which is difficult to justify as a normative matter. Simply because one person's pre-injury wealth has allowed her to adjust more successfully to disability, she would be compensated more; simply because another's pre-injury lack of wealth has made it more difficult for her to adjust to disability, she would be compensated less.

Phrased somewhat differently, the marginal utility variable is undeniably affected by a factor-pre-injury wealth-about which it is particularly difficult to generalize as a practical or normative matter. And wealth is not the only such factor. Other factors that are relevant to the marginal utility variable-such as spiritual or philosophical beliefs, the existence and supportiveness of family and social networks-raise similar scheduling problems. Generalizations about how these factors affect the marginal utility variable are problematic as a statistical matter and troublesome as a normative matter. Yet the potential accuracy of a scheduled approach inevitably decreases as the schedule omits factors relevant to the item or loss that the schedule purportedly addresses.

A second problem with the use of a marginal utility schedule relates to the effects of error in this context. All schedules, of course, sacrifice some level of accuracy, and the acceptability of such sacrifices depends on a range of factors. One should notice, however, that

110 Id.

111 See id. at 47-48 (explaining how and why a person who was previously economically well-off may be better equipped to select and supervise assistants effectively). The point is not that wealth dictates such success, but that statistically it may be a major influence in this respect. 
errors in the marginal utility calculation may have particularly devastating effects in the kingdom of the ill. Because the insurance theory uses the marginal utility variable to adjust compensation above or below the level of pecuniary loss, that variable can substantially affect a disabled individual's basic quality of life. For example, adjustments above the level of pecuniary loss could translate into independent living services, vocational retraining or education, and travel or other recreational activities; and adjustments below the level of pecuniary loss could render many of these items uncovered. Nothing in the insurance theory provides any way to cushion the effects of those errors. ${ }^{112}$

In sum, although all scheduled approaches pose tradeoffs between accuracy and cost, the set of scheduling tradeoffs raised by the marginal utility variable is especially suspect. The marginal utility variable (1) seems especially likely to raise severe accuracy concerns, (2) is crucial to the insurance theory's allocation of payments and thus dictates decisions about payments that have much to do with fundamental quality of life issues, and (3) is not cushioned or backed up by any other aspect of the theory.

\section{The Distinction Between Pecuniary AND NONPECUNIARY LOSSES}

The distinction between pecuniary and nonpecuniary losses also plays a crucial role in the insurance theory. This categorization question is a significant step in determining whether a particular loss is compensable. ${ }^{13}$ If a loss is deemed pecuniary, the theory calls for full

112 By contrast, an approach that has recently received increased attention in the workers' compensation setting makes use of more comprehensive schedules supplemented with a backup compensation standard that affords additional benefits to claimants whose disability seems more severe or permanent. See, e.g., Monroe Berkowitz \& John F. Burton, Jr., Permanent Disability Benefits in Workers' Compensation 407-12 (1987). Professors Berkowitz and Burton argue for a two-level benefit system that would begin with a comprehensive schedule of impairment-based payments, based on a rating system such as that of the American Medical Association. Id. Because these scheduled benefits would generally not vary according to the particular vocational circumstances of the worker, Berkowitz and Burton also advocate supplementing the scheduled benefits with benefits tied to the worker's actual wage loss. Id.

113 The insurance theorist might argue that the distinction is ultimately not that crucial because, however a loss initially is classified, the compensation decision will turn on the issue of postinjury marginal utility. Although this point has theoretical merit, in practice the distinction likely will be a critical one. See infra text accompanying notes 131-32. 
compensation unless the nonpecuniary losses reduce the postinjury utility of money, in which case compensation will reflect that utility discount. ${ }^{114}$ If a loss is deemed nonpecuniary, however, the theory calls for no compensation unless the nonpecuniary losses increase the marginal utility of money. In that case, compensation may be greater than the level of pecuniary loss. ${ }^{115}$

This Part shows that the pecuniary-nonpecuniary distinction cannot give meaningful guidance about a wide range of questions that will arise. Under the most plausible interpretation, the "pecuniary loss" category is so expansive that in practice a program would likely temper that expansiveness in some way, either by relying primarily on marginal utility calculations-with all the problems they pose-or by turning to decisional standards that the theory does not provide. In addition, the distinction at times implicates a concern similar to that explored in Part II: the distinction may turn on judgments that partly result from social and attitudinal barriers faced by the disabled.

Given the importance of the pecuniary-nonpecuniary distinction to the insurance theory, one would expect the theory to offer a meaningful degree of direction about how the various consequences that may follow injury should be characterized, particularly when those consequences are not rare. As I will demonstrate, the insurance theory fails to provide this critical guidance.

Insurance theorists provide several explanations of the distinction between pecuniary and nonpecuniary losses. The most thorough definition, and the one that appears to form the basis of most other analyses, describes a pecuniary loss as the loss of a "replaceable" good and a nonpecuniary loss as the loss of an "irreplaceable" good. ${ }^{116}$

114 See supra text accompanying notes 28-33.

115 See supra text accompanying notes 31-41. As noted, some theorists, notably Professor Schwartz, argue that compensation should not extend much, if at all, beyond pecuniary losses even if nonpecuniary losses increase the marginal utility of money. See Schwartz, supra note 9; supra text accompanying notes $36-41$. Others have criticized this contention. See Hanson \& Logue, supra note 43, at 184-86. For my criticism of Schwartz's argument, see supra note 41 .

116 Cook \& Graham, supra note 23, at 144-46. Later theorists explicitly rely on Cook and Graham's definition. See Arlen, supra note 25, at 56 n.64; Daniel A. Graham \& Ellen R. Peirce, Contingent Damages for Products Liability, 13 J. Legal Stud. 441, 446-47 (1984). Others give slightly different descriptions but do not seem to depart fundamentally from Cook and Graham. Professor Shavell, for example, defines pecuniary and nonpecuniary losses in basically the same terms as Cook and Graham, see Shavell, supra note 6, at 133, and he cites their article in his insurance theory discussion of such losses. Id. at 231. Professor Schwartz suggests that pecuniary losses are those that "both increase the consumer's marginal utility of 
Whether a good is replaceable depends on the subjective perspective of the owner: a good is replaceable "if the owner of the commodity perceives that equivalent commodities are available on the market" (such as a stereo) and irreplaceable if, in the owner's view, there are "no equivalent commodities . . . available on the market" 117 (such as mental functioning ability) or if the price of the equivalent good exceeds the owner's subjective valuation of the original good. ${ }^{118}$ To explore the application of this definition, consider the following injury and loss scenarios.

Case 1: An accident causes the loss of a $\$ 100$ bill; the receipt of $\$ 100$ fully restores the loss.

Case 2: An accident causes a broken finger. Medical services costing $\$ 1000$ completely restore the finger in every respect.

Case 3: An accident causes crushed vertebrae, but no paralysis results. A $\$ 5000$ operation (fusion and the insertion of metal rods) stabilizes the fracture and restores a great deal of functioning. But the person nonetheless will be left with permanent functional limitations (limits on bending, lifting, etc.).

Case 4: After an accident resulting in paralysis below the waist, an individual receives several months of acute medical care (including several operations) and a six-month stay in an intensive, in-patient rehabilitation center that specializes in rehabilitation of patients with spinal cord injuries. The center's program includes, among other items, group discussions, training in adapted recreation and daily care, and psychological counseling. After completing the program, the person enrolls in a community college in order to obtain a degree in computer science (previously, the person had been a real estate agent but now considers a computer science profession to be more

money and can be completely erased by monetary payments." Schwartz, supra note 9, at 363 . But he also cites Cook and Graham generally for the basics of the insurance theory. See id. at 362 n.13. In ary event, Schwartz's definition is not inconsistent with the "subjective equivalent" notion underlying Cook and Graham's definition. See infra text accompanying notes $117-18$.

Later analyses for the most part use the terms "pecuniary" and "nonpecuniary" to refer to replaceable and irreplaceable losses, respectively. See, e.g., Shavell, supra note 6, at 133, 22831; Arlen, supra note 25 , at 56 n. 64 .

117 Arlen, supra note 25 , at 56 n.64.

118 Cook \& Graham, supra note 23, at 144-45. Cook and Graham describe a commodity's value as "the owner's minimum selling price; the rate at which he is willing to exchange [the commodity] for 'all other goods;' or the minimum payment necessary to fully compensate him in the event that he loses [the commodity]." Id. at 144-45. 
adaptable in the long run to the disability). The person also wishes to modify her home and vehicle to make them optimal for purposes of independent living. Changes would include bathroom railings, lowered counters and stove tops, and ramps; transportation would require a new vehicle, such as a van, equipped with a wheelchair lift and fitted with hand controls.

Case 5: An accident victim suffers an injury that causes her to lapse into a coma. After stabilizing her and performing numerous tests, physicians advise the victim's parents to move their daughter to some form of long-term care facility, which would attend to feeding and other matters of daily care. Her parents have heard of a program called "patterning," in which a coma victim is bombarded with stimuli in an effort to stimulate all the senses (via touching, flash cards and other visual stimulation, massage, reading) and thus bring the person out of the coma. The physicians discourage the parents from undertaking this program and are pessimistic about the daughter's chances of emerging from the coma. Yet the parents, by using paid assistants as well as dozens of volunteers, begin the program; five months later, the daughter comes out of the coma. ${ }^{119}$

Case 6: An injury causes irreversible and permanent brain damage; no treatment or therapy can undo the damage or affect its functional consequences.

Cases 1 and 6 represent replaceable and irreplaceable commodities, respectively. Cases $2,3,4$, and 5 , however, reflect some of the most common sorts of losses: those that can only partially be addressed by medical care, rehabilitation, or other services. How the insurance theory classifies these losses is crucial. If they are considered pecuniary losses, the theory generally allows full compensation for them. ${ }^{120}$ If, on the other hand, they are considered nonpecuniary, no compensation will be payable unless the nonpecuniary losses increase the marginal utility of money. The classification questions posed by these cases are quantitatively significant, because the world of loss often presents these or similar situations. ${ }^{121}$

119 This example is drawn loosely from a case study described in Cost of Injury, supra note 92, at 173-75.

120 If marginal utility is assumed to decline postinjury, however, less than full pecuniary coverage will be allowed. See supra text accompanying note 33 .

121 The examples in Cases 4 and 5 pose classification issues similar to those presented in ten case studies recounted in Cost of Injury, supra note 92, at 139-78. As the report states, "the case studies were carefully chosen to be widely representative of injury and its aftermath." Id. 
One might contend initially that expenditures for items such as independent living services and vocational rehabilitation are "replaceable" losses under the insurance theory, because such expenditures can be fully replaced by money. This is not, however, the theory's likely answer, because this reasoning would qualify every postinjury expenditure as a replaceable, pecuniary loss. The theory's focus, instead, must be on the initial loss itself and whether it is "replaceable"; 122 that is, whether an "equivalent commodity" is available on the market for the person's initial loss.

But in Cases 3, 4, and 5, the initial losses (the injured back, the paralyzed body, and the lost mental and functional capacity, respectively) technically are not replaceable, because equivalent commodities are not available on the market. This is true even with Case 3, involving the back that can be surgically repaired but not completely restored. Hence, if the replaceability test is applied to the original loss as a whole, then even those losses addressed by basic medical care are not pecuniary unless that medical care is completely restorative. This seems unlikely to be the intended effect of the definition. ${ }^{123}$

Another interpretation is possible. Perhaps the test of replaceability should be applied to component aspects of the loss, rather than to the loss as a whole. Hence, to the degree that the steel rod surgery will restore functional capacity, flexibility, or strength,

at 140. Adaptive housing, for example, "refers to special living arrangements that provide an ensemble of services (attendant care, food, and transportation) to physically impaired persons who cannot live effectively in traditional housing" yet do not need an institutional setting. Stock \& Cole, supra note 95 , at 206 . Such housing might be beneficial to those who, "by congenital deformity, trauma, or progression of disease, have significant limitations in performing activities which necessitate daily living assistance in transferring from bed to wheelchair, eating, dressing, and other personal needs." Id.

The patterning example might seem more far-fetched, but many cases raise this or similar classification problems. For instance, head injuries and strokes that do not result in permanent coma nonetheless often cause functional and neural deficits that can be addressed by rehabilitation-training in daily life and independent living skills, behavior management, and speech therapy. Patients might benefit from months or even years of these treatments. See John Whyte \& Mitchell Rosenthal, Rehabilitation of the Patient With Head Injury, in Rehabilitation Medicine, supra note 68, at 585, 592-93 (describing these methods of rehabilitation).

122 For example, Professor Schwartz describes pecuniary losses as losses that "can be completely erased by monetary payments." Schwartz, supra note 9, at 363.

123 Virtually every insurance theory analyst mentions basic medical expenses as an example of a pecuniary loss. See, e.g., Shavell, supra note 6, at 228; Schwartz, supra note 9, at 367 (referring to medical expenses as a "core" pecuniary loss). 
that degree of functional capacity, flexibility, or strength is a loss for which an equivalent commodity exists (the restoration effected by medical care). This "particularized" approach to categorizing loss appears to be a more plausible reading of the literature than the "gestalt" approach, which, as described, would count as nonpecuniary even those losses that could be largely corrected by basic medical care.

If one were to apply this particularized interpretation, virtually every expenditure described in Cases 3,4 , and 5 would be viewed as replacing a pecuniary loss, because each service or item listed in those cases could effect an outcome that is equivalent to some aspect of loss. The household assistant's services are not equivalent to the ability to move oneself out of bed, but might be seen as generally equivalent to mobility from bed to elsewhere; the effects of vocational rehabilitation might not perfectly restore the person's previous employment capacity but might be equivalent to an aspect of that capacity, such as a certain income stream or level of satisfaction.

Only one limitation on the expansive, particularized approach to "pecuniary" losses exists: a loss is irreplaceable (thus nonpecuniary) if the price of the equivalent commodity exceeds the owner's valuation of the loss. ${ }^{124}$ Hence, the paraplegic's inability to get out of bed is a pecuniary loss only if the price of an equivalent good, such as an attendant's services, does not exceed the amount the owner would have demanded to relinquish the ability to get out of bed in the first instance. Thus, if an individual would have demanded $\$ 500,000$ in exchange for losing the ability to get out of bed and if the attendant's price is less than $\$ 500,000$, the attendant's services may be treated as compensation for a pecuniary loss under the particularized approach.

Under the particularized approach, then, drawing the distinction between pecuniary and nonpecuniary losses requires both the owner's subjective judgment about whether an equivalent commodity is available for particular aspects of various losses and the owner's subjective

124 Cook and Graham list several methods for determining such valuation, including the owner's selling (or asking) price for the original commodity. Cook \& Graham, supra note 23, at 144. Later, their discussion moves into an analysis of valuation by offer price; that is, by the amount the individual would be willing to pay to avoid losing the commodity. See id. at 146. As is commonly observed, offer and asking prices may diverge significantly according to the wealth of the individual. See Baker, supra note 107, at 13-22; Cook \& Graham, supra note 23, at 147 . 
valuation of the loss. In practice, however, this approach cannot give meaningful guidance about many of the classification choices that will arise. This is true because the expansiveness of the approach will be difficult to address in an acceptable way.

To understand this expansiveness and the possible ways of addressing it, suppose that the only rehabilitative or substitute service for some aspect of loss was exotic travel or that the only substitute for the loss of a loved career was expensive retraining and education in a different field. Under the particularized approach, these-and virtually any other rehabilitative or substitute item-could be deemed replacements for some aspect of loss. A program employing this approach, then, would have several options, each of which is troublesome: it could (1) give compensability status to virtually any postinjury rehabilitative or substitute expenditure, (2) rely primarily on the marginal utility variable-with all the problems outlined earlier-to make decisions about the vast world of postinjury expenditures, ${ }^{125}$ or (3) resort to decisional standards that the insurance theory simply does not provide.

The pecuniary-nonpecuniary distinction would be limited to these unattractive options even if, as to any given particularized loss, only one possible rehabilitative or substitute item was available, as in the example just given. The problem intensifies when one realizes that the assumption of one available rehabilitative or substitute option is unrealistic in many cases. With respect to many particularized losses, one could point to different potential replacements-such as cash, prosthetics, or retraining. As Sandra Tanenbaum explains in her detailed study of how various disability programs disseminate rehabilitative technologies:

No prosthesis can fully replace the human arm; rehabilitation engineering can hope to reproduce only some subset of arm functions and meanings. Thus a prosthesis is always less than adequate, and nonprosthetic strategies, like learning to cook with one hand, are neither

125 In theory, of course, the ultimate compensability decision as to any item of loss depends on a marginal utility calculation. In practice, however, one would expect that the distinction between pecuniary and nonpecuniary loss would determine the presumptive compensability status of many items, assuming that the distinction could be applied in a meaningful way. If the distinction could not perform that presumption-setting role, then the insurance theory, in practice, would require a set of marginal utility calculations about every aspect of loss. For all the reasons outlined earlier, this is an unacceptable prospect. 
useless nor necessarily inferior to wearing a prosthetic device. The same is true in a less obvious way of measures like preference in federal hiring and disability compensation payments. These represent alternatives to physical restoration when the latter is viewed as a means to financial independence. ${ }^{126}$

When several possible substitute or rehabilitative choices are available as to a given loss, this intensifies the expansiveness of the pecuniarynonpecuniary distinction, and it underlines the problems with the various methods of addressing that expansiveness.

The insurance theory's proponents, however, might fashion a response to these criticisms of the pecuniary-nonpecuniary distinction. The response would begin with the quite realistic assertion that a program making use of the insurance theory would not apply the distinction on a case-by-case basis. Rather, the program would generalize, either across the board or with respect to defined categories of cases, about the typical subjective judgments that individuals would make about the replaceability of various losses. For example, a pecuniary-nonpecuniary "schedule" could specify that cognitive therapy and vocational retraining (but not travel) are replacements for some aspects of chronic pain and thus receive presumptive compensability status. The use of such generalizations, one could argue, would serve as a kind of boundary to the potential expansiveness of the distinction between pecuniary and nonpecuniary losses. This boundary, moreover, would not presuppose decisional criteria that the theory does not provide.

This approach might be acceptable if there were some meaningful way to generalize about most of the classification choices that will arise. Because most individuals presumably view $\$ 100$ as equivalent to a lost $\$ 100$, and because their valuation of the loss matches the definition, then classifying this as a pecuniary loss is sensible. The same would be true if we had good reason to suppose that most individuals would make similar subjective judgments about less obvious choices-the case of the completely restorative surgery might be an example. So long as the generalization seemed statistically valid, its

126 Sandra J. Tanenbaum, Engineering Disability: Public Policy and Compensatory Technology 63 (1986). 
use could probably be characterized as a preference-derived classification choice. ${ }^{127}$

More difficult are the other classification tasks illustrated in the examples-independent living services, partially restorative therapies, and other substitute services or activities. For this significant spectrum of possible replacement strategies, a schedule that relies solely on subjective determinations about replaceability and valuation seems inadequate for several reasons. ${ }^{128}$ First, acceptable generalizations about these tests may not be possible, at least as to some potential replacements. Such generalizations may stumble on the complexity of the necessary inquiries or on the distribution of responses that would be made to such inquiries.

The program, for example, would have to generalize about subjective responses to the following sorts of queries. To what losses are the personal attendant's services equivalent, and what is the value of those losses relative to the price of the attendant? To what sorts of losses are the effects of vocational rehabilitation equivalent, and what is the value of those losses relative to the price of rehabilitation? These judgments depend not just on objective factors (such as physiological data and market prices) but also on environmental factors and personal attributes such as moral and religious principles, optimism, independence, self-esteem, and wealth. The fact that a number of potential replacement options may be available for any particular loss further complicates the task of generalization. With respect to the amputation of an arm, for example, potential (and partly competing) means of replacing some of the resulting losses include different types of prosthetic devices, retraining, personal attendant services, and environmental modifications. ${ }^{129}$

127 Cf. Smith, supra note 60, at 1135 (noting that, with respect to quality-adjusted life-years in the medical context, "one might question large samples of individuals . . . and calculate an average value for each disorder" and "[p]rovided that the variance was not too great, it might be reasonable to represent these average values as expressions of a general consensus").

128 The theory relies solely on this standard to distinguish between pecuniary and nonpecuniary losses. The ultimate compensability decision, however, may turn on a further judgment about marginal utility. Nonetheless, the initial pecuniary-nonpecuniary classification is likely to have significant practical significance, despite the arguable adjustment that might result from the marginal utilty variable. See infra text accompanying notes 131-32.

129 See Tanenbaum, supra note 126, at 10-13 (describing various compensatory strategies that might be used in loss contexts, such as the loss of an elbow, and explaining how these strategies differ and why preferences about them might vary). 
Because studies or data purporting to address the issue of replaceability (or any analogous point) do not exist at present, it is difficult to predict how an effort to generalize would fare. But it is instructive to note the observations of Sandra Tanenbaum's study of how various societal disability programs diffuse and distribute compensatory technologies, in particular a myoelectric prosthetic known as the "Boston Elbow." At the outset of her book, Tanenbaum explains why compensatory techniques may provoke quite dissimilar reactions among those who might benefit from them:

Rehabilitation technologies mitigate functional loss . . . . [F]unctional loss is basic and serious. By definition, it is an inability to carry out major activities of daily living, and it resembles physical and mental illness in this regard. ... Unlike illness, functional loss is ... embedded and idiosyncratic. It is by definition the frustration of an individual's efforts to get along in his or her own environment. Disabled individuals may not understand the physiological basis of what they experience, but they know best its functional implications. There are many ways to meet a functional need, and humans design compensatory strategies by bringing to bear myriad details of residual functioning and of the environments with which they must contend. ${ }^{130}$

Second, even assuming one could derive the necessary generalizations as a quantitative matter, the use of such generalizations could raise problems similar to those outlined in Part II's discussion of marginal utility. Subjective judgments of replaceability might be affected by devaluative assumptions about disability as well as by social and attitudinal barriers relating to disability. Consider, for example, decisions about whether and to what degree a personal attendant's services will replace lost functional capacities; whether adapted or dramatically altered recreational activities could replace one's existing sporting activities; whether physical therapy aimed at restoring function and flexibility following severe and disfiguring burns will restore anything that matters to an individual who now must function in this society in a grossly disfigured state. Subjective judgments that no meaningful replacement exists in these scenarios might result in part from unjustifiable disability-related assumptions, attitudes, and barriers. Such factors could also affect judgments about replaceability

130 Id. at 6-7 (emphasis omitted). 
when several possible replacement strategies are available. For example, a disabled individual might consider individual taxi services rather than modified buses to be the appropriate "replacement" for reduced mobility; this judgment might predominantly result from her negative experience of how others react to her in public settings.

In sum, the insurance theory fails to give meaningful guidance about an issue-the distinction between pecuniary and nonpecuniary losses-that is critical to the theory's operation. The most plausible interpretation of the distinction - the particularized loss approach-is so expansive that, in practice, it would need to be tempered with decisional criteria that the insurance theory does not provide. These concerns do not find an adequate response in the possible use of a schedule that generalizes about subjective judgments relating to replaceability. In addition to the practical difficulties of arriving at such generalizations, the schedule-like the theory's marginal utility variable-would incorporate subjective reactions to disability-related issues without noting or in any way adjusting for the influence of discrimination and devaluation.

The point here is not that the insurance theory creates difficult issues relating to the valuation and coverage of postinjury rehabilitative, substitute, or replacement services. Any theory eventually must grapple with such issues. But the insurance theory's approachwhich purports to rely on nothing but subjective judgments of replaceability and valuation-is an especially unattractive one, for the reasons outlined above.

In reply, the insurance theorist might contend that these criticisms overstate the significance of the distinction between pecuniary and nonpecuniary losses. The theorist could point out that the compensation decision ultimately depends not on the pecuniary-nonpecuniary classification, but on whether, how, and to what degree the marginal utility of money is affected by the injury. Thus, the marginal utility determination could address or adjust for any problems with or errors in the classification of a loss under one heading or the other.

In practice, however, the classification of losses as pecuniary or nonpecuniary will likely set the default position or presumptive compensability status of many items; in individual cases this setting could 
ultimately carry the day for a variety of reasons. ${ }^{131}$ In any event, it is small comfort to defend the pecuniary-nonpecuniary distinction with the corrective potential of the marginal utility variable. This would only increase the practical import of and, thus, exacerbate the significant failings of the marginal utility variable itself. ${ }^{132}$

\section{Normative Arguments Relating to the Theory}

The problems discussed in the two preceding Parts cast serious doubt on the practical and moral acceptability of the insurance theory, regardless of which normative premise is said to support it. This Part delves further into the normative weaknesses of the theory. An examination of the theory's possible normative foundations, of course, implicates a much wider debate over the merits of these various principles. For example, to the extent the theory rests on an efficiency or consumer sovereignty maxim, one could apply to the theory the host of objections that have been leveled at various efficiency standards by law and economics critics. ${ }^{133}$ Rather than recounting these larger debates, however, this section will focus on the specific objections that seem especially noteworthy in the context of the insurance theory.

This Part first explains the shortcomings of the most intuitive case for the theory-the claim that it is appropriate to critique largely

131 For example, the marginal utility variable, which almost certainly would be a scheduled determination, see supra text accompanying notes 103-05, inevitably will be applied in a way that does not result in a perfect "fit" in a number of cases. To the extent this is so, the initial classification as pecuniary or nonpecuniary assumes greater significance. In addition, the practical significance of the distinction would increase in programs that accepted Professor Schwartz's approach to nonpecuniary losses that increase the marginal utility of money. As outlined elsewhere, see supra notes $37-41$ and accompanying text, Schwartz contends that nonpecuniary losses should not be compensated to the full extent of the marginal utility increase they cause. Thus, under his view, the initial classification of an item as pecuniary or nonpecuniary assumes even greater significance.

132 Consider, for example, the effects of relying on the marginal utility variable to determine the compensability of all but the "consensus" items (the \$100) illustrated in the cases described supra text accompanying notes $118-20$. This would require marginal utility determinations with respect to the full spectrum of corrective, rehabilitative, and substitute items, such as surgery, medical rehabilitation, independent living services, and adaptive activities.

133 For just a sampling of the criticisms, see Mark Kelman, A Guide to Critical Legal Studies 114-50 (1987); Baker, supra note 107; Jules L. Coleman, Efficiency, Utility, and Wealth Maximization, 8 Hofstra L. Rev. 509 (1980); Ronald M. Dworkin, Is Wealth A Value?, 9 J. Legal Stud. 191 (1980); Robin West, Authority, Autonomy, and Choice: The Role of Consent in the Moral and Political Visions of Franz Kafka and Richard Posner, 99 Harv. L. Rev. 384 (1985). 
insurance-based systems (such as tort) with insurance-related criteria. Second, it describes the ways in which the insurance theory fails to ensure efficiency, even assuming that an efficiency principle alone would support the theory. The final two Sections detail various problems with justifying the theory by invoking principles of autonomy or contractarianism. ${ }^{134}$

\section{A. The Intuitive Case: Insurance Systems Deserve an Insurance-Oriented Critique}

The insurance theory seems easiest to defend when applied to social programs that function primarily as insurance systems: if a program rests on an insurance rationale, surely it is appropriate to critique that program according to insurance-related criteria. But even this seemingly uncontroversial defense falls short in the context of tort or many possible tort modifications. Even granting that the modern tort system and at least some tort replacements primarily function as insurance schemes, ${ }^{135}$ corrective justice concerns could still continue to play a role. To the extent that these corrective justice concerns apply, the insurance theory's normative guidance in these contexts is quite limited. Most obviously, to the extent that corrective justice plays a role, one always could justify compensation features such as significant noneconomic compensation that do not match the directives of the insurance theory.

To this observation, however, the insurance theory's proponents could reply that, assuming the primacy if not the exclusivity of a lossspreading function, the theory still generates guidelines that are at least generally applicable in a critique of tort. This response is incomplete.

Even if corrective justice is assumed to play a subsidiary or even peripheral role, it still might serve as a veto to the insurance theory's implications. ${ }^{136}$ Under most accounts, corrective justice focuses on

134 Because the arguments from autonomy and utility are so similar, I treat them in the same subsection.

135 See, e.g., 2 ALI Reporters' Study, supra note 10, at 207.

136 Even if a particular compensation or accident law system is not aimed primarily at furthering some justice-related goal (such as distributive or corrective justice), justice concerns can and should have a sort of veto power over the program. Dean Calabresi explained this notion of justice in The Costs of Accidents, see Calabresi, supra note 16, at 24-26, and elaborated on it in a later work. See Guido Calabresi, About Law and Economics: A Letter to Ronald Dworkin, 8 Hofstra L. Rev. 553, 557-60 (1980). 
the relationship between an injured victim and a culpable actor ${ }^{137}$ and, when applicable, translates in part into a moral demand that the wrongfully injured person's losses be annulled (i.e., that the person be somehow restored or fully compensated). ${ }^{138}$

When corrective justice plays only a peripheral role, one certainly can justify some sort of departure from full compensation. But the particular type of departure that the insurance theory represents is quite troublesome. Consider a victim of severe burns for whom the postinjury marginal utility of money is less than pre-injury marginal utility, because her pain and disfigurement render most postinjury activities far less pleasurable. Suppose, too, that her pecuniary losses equal $\$ 50,000$.

Given the reduced role of corrective justice, one could accept a measure that fell short of compensating this victim for the full dimensions of her injury. But, even if corrective justice spoke in a weaker voice, it would reject the compensation measure under the insurance theory. Had the burn victim suffered some injury that caused $\$ 50,000$ in pecuniary loss but did not affect her marginal utility of money, she would receive the full $\$ 50,000$. Here, she will receive less precisely because the injury has damaged the quality of her life. The very injury that is in some sense wrongful and that we seek to redress to

137 See 2 ALI Reporters' Study, supra note 10, at 204-05; Richard A. Posner, The Concept of Corrective Justice in Recent Theories of Tort Law, 10 J. Legal Stud. 187, 190-91 (1981). Under some accounts, tort law does and should grow out of this focus on the relationship between culpable actor and injured victim. See, e.g., Erniest J. Weinrib, Understanding Tort Law, 23 Val. L. Rev. 485, 510-14 (1989). Jules Coleman's careful analysis of corrective justice argues that in some respects this traditional account of corrective justice is inadequate to explain tort's rule that the faulty injurer recompense the injured victim. Although corrective justice means that wrongful losses should be "annulled," it does not mean that victims' losses always should be imposed on their injurers. See Jules L. Coleman, Markets, Morals and the Law 186-88, 197 (1988).

138 One could agree that corrective justice requires restoration or full compensation and still disagree over the exact means of accomplishing this (e.g., making the injurer provide transportation assistance to the mobility-impaired victim versus making the injurer pay for the costs of adapted transportation). Thus, corrective justice does not answer all questions about the method or amounts of compensation, even assuming agreement on the relevance of corrective justice. Nonetheless, corrective justice usually has been thought to provide the basis for some sort of full compensation or restoration demand. See 2 ALI Reporters' Study, supra note 10, at 204-05; Coleman, supra note 137, at 186-89, 200-01; Weinrib, supra note 137, at 524. Professor Coleman argues that corrective justice does not demand that the faulty injurer always be required to compensate the victim; but he notes throughout his analysis that corrective justice requires that victims' losses be "annulled" or "repaired." See Coleman, supra note 137 , at $187,197-201$. 
some degree even under a reduced corrective justice principle is itself the insurance theory's justification for reducing compensation even further.

One might try to remedy this problem by applying the insurance theory minus its conclusions about declining marginal utility and wealth effects. Such a version of the theory would support noneconomic compensation with respect to injuries that increase the marginal utility of money. This point underlines the conclusion stated above: when corrective justice concerns play a role (even a subsidiary one), the theory at best generates only a quite general critique: it casts doubt on the extensive noneconomic compensation that tort law currently allows. The theory simply cannot give meaningful guidance as to how much noneconomic compensation is justified.

To recapitulate, the most obvious case for the insurance theory falls short in any context where corrective justice continues to play a role. Even if that role is only a subsidiary one, corrective justice concerns would veto any approach that would reduce compensation on the basis of a factor that itself is the product of an injury that is in some sense wrongful and that to some degree we wish to redress. The insurance theory's assumptions about the postinjury marginal utility of money are just such a factor.

\section{B. Efficiency and the Insurance Theory}

Relatively few normative justifications have been directly advanced for the insurance theory. ${ }^{139}$ Yet insurance theorists agree that the theory reflects efficient compensation, ${ }^{140}$ and this claim triggers a host of normative arguments that have been advanced on behalf of various efficiency standards. ${ }^{141}$ Before I address some of these arguments in detail, it is important to note some basic shortcomings with the claim that the insurance theory reflects efficient compensation.

139 Professor Schwartz has given the most detailed normative discussion relating to the theory. He explains why a "consumer sovereignty" maxim ought to govern products liability cases and why the insurance theory is consistent with such a maxim. See Schwartz, supra note 9, at 357-67.

140 See supra notes 43 and 44.

141 See, e.g., Coleman, supra note 133 (describing various efficiency standards and exploring arguments that might be made on their behalf); Posner, supra note 50 (defending wealth maximization as a normative principle); Schwartz, supra note 9, at 359-60 (arguing that a contractarian view would support the selection of utility maximization as the meta rule that should govern products liability). 
Put simply, the insurance theory looks at efficiency through too narrow a lens: it aims for efficiency only with respect to intrapersonal loss-spreading. This is evident from the theory's focus on mimicking, at a societal level, the insurance choices that a utility-maximizing individual would make. For a variety of reasons, however, an individual's utility-maximizing calculus may yield inefficient calculations.

First, the utility-maximizing individual, when making insurance choices, might not take all costs of injury into account. The most obvious category of such costs is the support and care services that will be performed by third parties if no insurance is purchased, such as the costs of unpaid attendant care to assist with transportation, inhome mobility, eating, dressing, and other personal needs. ${ }^{142}$ According to a congressionally commissioned report on injury in the United States, "there are no reliable data from which to make estimates" of "the services of family members and friends who care for the injured." "143 Yet, "[t]his 'informal care' cost is likely to be significant, as illustrated by the case studies" recounted in the report. ${ }^{144}$ Another example of such costs is the psychological effects of disability on the family of the disabled individual. ${ }^{145}$ These effects include stress, anger, fear, and anxiety; together or alone, these effects can be significant enough to unravel preexisting relationships. As one rehabilitation expert explains, "When the patient is discharged, even a stable family may be overwhelmed by the magnitude of the disability. . . . Families run out of energy both physically and psychologically in a constant effort to be adequate." 146 Counseling and support services for family members may assist in relieving, if not eliminating, these burdens. ${ }^{147}$

142 See Richard V. Burkhauser \& Robert H. Haveman, Disability and Work: The Economics of American Policy 19 (1982) (noting that some such costs are often borne by the injured person's family); Christiansen et al., supra note 104, at 110-11 (describing possible functions of personal care attendants).

143 Cost of Injury, supra note 92 , at 82.

144 Id.

145 “'[A]lthough only one member of the family 'owns' the disability, all family members are affected and, to some extent, handicapped by it. . . . The disability of one may alter the lifestyles of family members as much or more than that of the disabled invidual . . ." Vash, supra note 75 , at $54-55$.

146 Hilda P. Versluys, Physical Rehabilitation and Family Dynamics, in The Psychological and Social Impact of Physical Disability, supra note 70, at 102, 109.

147 See Stanley Ducharme, Kathleen Gill, Susan Biener-Bergman \& Louisa Fertitta, Sexual Functioning: Medical and Psychological Aspects, in Rehabilitation Medicine, supra note 68, at 
As to this significant category of costs, the utility-maximizing individual might choose not to insure or to underinsure, because someone else will have to bear them. Yet, allowing these costs to fall on third parties may often be inefficient. At a minimum, then, an efficiency rationale requires a broader inquiry that asks what "insurance" choices would be made by all individuals who might bear such costs of injury.

In addition, the intrapersonal perspective fails to account for a number of less monetizable costs of injury that will not be borne by the injured individual. ${ }^{148}$ Consider an individual who decides that substantial pain or functional limitations would significantly lower her marginal utility of money. (She knows, for example, that she would value adapted transportation and travel far less than she values mobility when unimpaired.) Thus, she insures herself for less than her potential pecuniary loss and does not buy coverage for nonpecuniary losses, such as impairment or pain. This choice, which is considered utility-maximizing under the insurance theory, would leave her, once injured, without coverage for full rehabilitation costs or "substitute" living arrangements (such as a handicap-accessible car).

This postinjury state, however, poses costs for other members of society. Other individuals might experience a reduced sense of welfare upon knowing that others do not have access to goods or services (such as modified transportation) that could significantly enhance their quality of life. Other individuals, committed to the notion that everyone should be engaged in some gainful activity, might be disturbed that the injured person will not receive vocational rehabilitation. The list of these third-party intangible costs could go on; they could stem from compassion for the injured, from a commitment to rehabilitation, to work, or to some modicum of purposeful activity. Although they are difficult to list exhaustively or to convert into pecuniary terms, these costs are real consequences of injury-costs that will be unaccounted for under a purely intrapersonal accounting.

519, 533-34 (describing marital and sexual adjustment therapy for couples with a disabled member); Versluys, supra note 146, at 11-15 (describing ways in which counseling and support may help the families of the disabled, both in their own adjustment and in assisting the disabled family member).

148 Economists Richard Burkhauser and Robert Haveman have used the term "collective compassion costs" to describe these intangible effects. See Burkhauser \& Haveman, supra note 142 , at 19. 
Only if the insurance theory is willing to disregard all such costs is the intrapersonal perspective adequate from an efficiency perspective.

\section{Autonomy and Utility Arguments}

Insurance theorists might base several normative arguments on the descriptive contention that the theory basically matches the choices that individuals actually make in private and social insurance schemes. For example, neither social nor private insurance programs provide significant levels of nonpecuniary compensation - a result consistent with the maxims of the theory. ${ }^{149}$ If one is persuaded that the insurance theory expresses or is not far removed from individuals' actual, revealed preferences about appropriate compensation, one could advance autonomy or utility arguments on behalf of the theory. ${ }^{150}$ As to autonomy, one could contend that deference to revealed preferences is generally the surest path to promoting individual autonomy and preventing unwarranted collective interference with individual choice. ${ }^{151}$ The utility argument would contend that revealed

149 See 2 ALI Reporters' Study, supra note 10, at 207 (insurance theory's arguments against significant nonpecuniary compensation "find considerable empirical support in the relative paucity of such insurance in the private or public programs through which the community now provides first-party loss insurance to itself"); Danzon, Tort Reform, supra note 8, at 52224.

150 Professor Schwartz, however, does not accept the argument that existing patterns of insurance coverage are conclusive evidence of consumer preferences. For example, he points out that individuals' failure to insure against mental losses may be caused by supply-side difficulties in providing such coverage. Schwartz, supra note 9, at 364-65. In spite of this position, he seems to argue that the insurance theory is not far removed from an actual consent justification. As to the consumer sovereignty norm (the overall principle that he argues should govern products liability), Schwartz states, "[i]t is plausible to suppose . . . that real people do want to minimize the amount of risk to which they are exposed, but not to spend excessively on risk reduction." Id. at 358 . In addition, he notes that product consumers could revoke by contract the rules that the consumer sovereignty approach otherwise would implement. Id. This latter point, of course, would be inapplicable to many other contexts in which the insurance theory could be applied. And although the former point might be plausible, it is a long way from the specifics of the insurance theory. Real people might want risk-spreading at nonexcessive prices, but this general preference could support a range of damage approaches in addition to the insurance theory.

151 See Cass R. Sunstein, Legal Interference with Private Preferences, 53 U. Chi. L. Rev. $1129,1131-36$ (1986) (outlining the liberty-autonomy arguments that have been made on behalf of deference to private preferences). 
preferences constitute meaningful, indeed the best, evidence of how to further subjective well-being. ${ }^{152}$

An initial problem with these arguments is the descriptive contention that underlies them. Even if existing social and private insurance schemes arguably match the theory, other causes for these coverage patterns are likely to exist, thus undermining the claim that these patterns reflect individual choices matching the maxims of the theory. For example, Professor Schwartz argues that "adverse selection"153 may be particularly relevant to the provision of insurance for some nonpecuniary losses. ${ }^{154}$ And, even if existing schemes matched the theory and reflected individual choice for the maxims of the theory, it does not follow that individuals will make such choices in future settings (for example, with respect to schemes intended to replace the tort system).

152 See Robin L. West, Taking Preferences Seriously, 64 Tul. L. Rev. 659, 665-66 (1990) (outlining the link between utilitarianism and deference to revealed preferences). In addition to the concerns discussed in the text, autonomy or utility arguments that rest on deference to actual or likely preferences also must come to terms with a large body of research that casts doubt on the decisionmaking model that forms the basis for the theory. According to this research, individuals do not process and analyze uncertain prospects according to the tenets of the "expected utility" model that underlies the insurance theory; that is, they do not add expected utilities and discount probabilities in statistically appropriate ways. Rather, they rely on heuristics and short-cuts that lead to systematic errors in judgments about the future. See Amos Tversky \& Daniel Kahneman, Judgment Under Uncertainty: Heuristics and Biases, in Judgment Under Uncertainty: Heuristics and Biases 3 (Daniel Kahneman, Paul Slovic \& Amos Tversky eds., 1982). The research has documented a number of such heuristics that are especially applicable to the insurance theory and its focus on the probability and effect of future injury. For example, an individual tends to assess the probability of a future occurrence by how representative it seems of phenomena with which that individual is familiar. See id. at 4. One suspects that this heuristic could affect insurance choices in several ways. For example, the "invisibility" of the disabled in many settings could lead the able-bodied individual to underestimate the likelihood of disability. In addition, the heuristic could lead to error in evaluating the nature or quality of life when disabled. Individuals might tend to focus on certain especially tragic disability scenarios and judge the nature of future disability on that basis.

153 Adverse selection is "the process by which low-risk insureds tend to purchase less coverage, and high-risk insureds tend to purchase more coverage," than either group would purchase if insurance could be priced exactly to reflect the actual risk that the individual faces. Kenneth S. Abraham, Distributing Risk: Insurance, Legal Theory, and Public Policy 15 (1986).

154 Schwartz, supra note 9, at 365. Thus, he concludes, the paucity of pain and suffering insurance "does not imply that [consumers] voluntarily eschew it." Id. See also Croley \& Hanson, supra note 43, at 61-63 (describing supply-side obstacles to insurance for nonpecuniary losses). 
In addition, these autonomy and utility arguments founder for a deeper reason. Although deference to existing preferences is commonly viewed as a sound route to promoting individual autonomy, ${ }^{155}$ others have argued that this view mistakes the origin and nature of private preferences. If preferences are not themselves the result of true autonomy, but the "product of available information, of existing consumption patterns, of social pressures, and of legal rules,"156 then it is difficult to equate the satisfaction of preferences with the promotion of autonomy. Similarly, the utility argument loses much of its potential normative force when viewed from this perspective, because a person's lack of desire for a good or opportunity may result from her perception that it will be denied to her. ${ }^{157}$

These criticisms have special force in the context of the insurance theory. As demonstrated earlier, the theory depends in crucial ways on subjective judgments about marginal utility and the replaceability of particular losses-judgments that are likely to be significantly influenced by discrimination against and devaluation of the disabled. ${ }^{158}$ Most obviously, these social forces may heighten the potential for incorrect judgments about the likelihood and nature of disability. In addition, and perhaps more importantly, these forces call into question the normative strength of even "correct" judgments about disability. For example, an individual may decide that disability will reduce the marginal utility of money in part because the opportunities available to her will be less varied and less pleasurable; this conclusion

155 See Sunstein, supra note 151 , at 1129-32 (describing this view).

156 Cass R. Sunstein, After the Rights Revolution: Reconceiving the Regulatory State $\mathbf{4 0}$ (1990).

157 Sunstein, supra note 151 , at 1146 . This weakness in utility theory is more fully outlined in Jon Elster, Sour Grapes: Studies in the Subversion of Rationality 109-40 (1983). Elster uses the phrase "adaptive preferences" to refer to preferences shaped by the individual's sense of limited opportunity. Id. at 110.

A more radical case against a preference-utility link is possible. As Robin West has explained, if one contends that "the individual who holds preferences is deeply irrational, motivationally as well as cognitively," see West, supra note 152 , at 673 , then the satisfaction of preferences plainly is not a route to maximizing well-being. See id. at 673-75. The normative flaws in the insurance theory, I believe, are apparent enough without resort to this more radical critique of utility theory.

158 As such, these judgments are good examples of "adaptive preferences"-preferences that result from limited opportunities. See Elster, supra note 157, at 110; Sunstein, supra note 151, at 1146. As Sunstein explains, "people fail to obtain goods that would turn out to be extremely rewarding, precisely because they do not want those goods, and their lack of desire turns on a lack of opportunities." Id. at 1147. 
may be based on her correct assessment of the social and attitudinal barriers faced by the disabled. Similarly, a person may decide that a disfiguring injury like a severe facial burn would dramatically reduce the value and pleasure of money to her. This judgment might also rest on a correct assessment of the societal ostracism she would face with such an injury.

Because these socially influenced preferences are central to the insurance theory's application, and given the pervasiveness and power of disability-devaluing social forces, the normative power of the autonomy argument for the insurance theory collapses completely. And this collapse is especially emphatic when one considers that the insurance theory would reinforce and intensify the impact of disability devaluation. Both erroneous and "correct" judgments about disability would reduce the amount of insurance "purchased"-perhaps even to a level significantly less than pecuniary loss. Yet the narrative and empirical information about the disabled continues to stress the centrality of money to disabled persons' independence, employment opportunities, and psychological and physical adaptation to postinjury life. A policy that allows systemic underinsurance will only further ensure that many of the disabled remain marginalized and unable to lead independent lives or participate fully in social activities. ${ }^{159}$

159 An autonomy argument also might rely on reasoning similar to Judge Posner's wellknown effort to justify wealth maximization according to consent. See Posner, supra note 50, at 491-97. Efficient rules often arguably produce ex ante compensation even for those who, ex post, will be disadvantaged by the rule. See id. at 492 . That is, the person who eventually will lose under the rule will have benefited at some earlier point. This argument could be applied to the insurance theory. Reliance on the insurance theory will reduce the premium "prices" that the tort system charges. Hence, even eventual "losers" under the insurance theory-those who are injured and receive less compensation than alternative rules would have providedwill have received an important benefit ex ante. In Posner's view, this ex ante compensation provides a morally adequate basis for many efficient rules. Id.

This argument has received severe criticism. See Guido Calabresi, The Pointlessness of Pareto: Carrying Coase Further, 100 Yale L.J. 1211, 1225 (1991); Coleman, supra note 133, at 531-40; Ronald Dworkin, Why Efficiency?, 8 Hofstra L. Rev. 563, 574-79 (1980); West, supra note 133, at 404-24. Several critics have pointed out that the argument requires at a minimum some showing that individuals would choose a Kaldor-Hicks or wealth-maximization principle rather than some other approach, such as the principles of John Rawls. See Calabresi, supra, at 1225; Coleman, supra note 133, at 539-40. It thus seems most appropriate to treat the consent argument under the discussion of contractarian theories. 


\section{Contractarian Justifications}

The insurance theorist might also look to a contractarian justification for the theory, which would ask what basic governing principles or meta-rules "persons would agree to were they made to choose in a situation stripped of morally irrelevant features." 160 A number of such meta-rules have been proposed, ranging from John Rawls' famous maximin approach ${ }^{161}$ to utility-maximization ${ }^{162}$ or to a "just wants" guarantee. ${ }^{163}$ A contractarian defense of the insurance theory would begin with the selection of some meta-rule or rules and then demonstrate the theory's compliance with that rule. Given the severe problems with relying on existing disability-related preferences, a contractarian justification for a compensation system is especially attractive: such an approach would not take existing preferences as its starting point, but instead would seek to derive the rules that individuals would choose under morally relevant conditions.

Even without engaging in a detailed debate over which meta rule or rules could or should be chosen under a contractarian approach, two features of the insurance theory are troublesome. ${ }^{164}$ The first is the

160 Schwartz, supra note 9, at 358. Professor Schwartz argues that a contractarian perspective supports choosing utility maximization as the meta rule that would govern products liability law. See id. at 359-60. Thus, the insurance theory-which would be consistent with the utility maximization meta rule-is supported by a contractarian perspective.

161 Rawls argues that two principles of justice would be chosen by those persons charged with selecting meta-principles. See John Rawls, A Theory of Justice 302 . He characterizes these principles as the "maximin solution to the problem of social justice," which "tells us to rank alternatives by their worst possible outcomes: we are to adopt the alternative the worst outcome of which is superior to the worst outcomes of the others." Id. at 152-53.

162 Professor Schwartz's contractarian argument employs utility maximization as the meta rule that should govern products liability. See Schwartz, supra note 9, at 358-60.

163 See C. Edwin Baker, Outcome Equality or Equality of Respect: The Substantive Content of Equal Protection, 131 U. Pa. L. Rev. 933, 963 (1983) (arguing that persons selecting the basic governing principles would choose several principles of justice, one of which would be that society ensure that all people "receive those resources and opportunities that the society treats as necessary for meaningful life and full participation in the community").

164 Professor Schwartz has argued that individuals would choose a principle of utilitymaximization, at least in the products liability context. See Schwartz, supra note 9, at 358-60. Those choosing a meta rule for torts "should know that states provide workers' compensation and disability insurance," and thus would realize that "the worst outcome-incurring serious, completely uncompensated injury-is substantially mitigated by existing social safety nets." Id. at 359. Although Professor Schwartz's concentration on the products liability arena allows him to assume a background safety net of disability insurance and workers' compensation, this background assumption is not an appropriate part of the case for the insurance theory more 
theory's distributional implications. To appreciate these, assume that individuals have adequate pre-injury wealth, either from social welfare programs or other sources. Now consider the effects of a serious injury or illness. A person who, prior to injury, had some level of independence and ability to work, to engage in recreation, or to participate in social and community activities, might find herself unable to continue doing so after serious injury. Even if her pre-injury level of wealth was adequate, this disabled person might be unable to purchase the education, retraining, services, and environmental adaptations necessary for some basic level of independence, social interaction, and vocational ability.

Under the insurance theory, it is not at all clear that this person would receive compensation sufficient to allow her to reach some meaningful level of independence or vocational and social activity. Even assuming that expenditures for these items would be presumptively covered under the pecuniary-nonpecuniary distinction, ${ }^{165}$ the marginal utility variable would reduce compensation below the level of pecuniary loss if the marginal utility of money declined postinjury. Although the marginal utility of money for items such as education, retraining, transportation, and environmental adaptations is presumably high, it might nonetheless be deemed lower than the pre-injury marginal utility of money as to some individuals or in some settings. ${ }^{166}$

To the extent the insurance theory would allow such results, it would be objectionable on the basis of many contractarian accounts,

generally. Instead, to justify the insurance theory as reflecting appropriate compensation in general, one could at most assume the existence of some poverty-related social safety net, such as welfare payments and unemployment compensation. Thus, individuals choosing the meta rules would realize that a utility-maximization principle, if translated into the insurance theory, could leave certain basic needs arising from serious illness or injury unaddressed (and uncompensated).

165 It is not at all certain that these items would receive presumptive coverage. As I argued earlier, the distinction between pecuniary and nonpecuniary loss will likely turn on decisional criteria that the insurance theory does not provide. See supra text accompanying notes 113-32. If some or all of the expenditures noted above are not presumptively compensable, it is even more likely that they will remain uncompensated under the theory.

166 Even if programs arrived at an increased postinjury marginal utility conclusion, the insurance theory, under at least one version, see Schwartz, supra note 9, at 365-66, would not permit increased levels of compensation to reflect this. See supra text accompanying notes 3740 (describing Professor Schwartz's "income effects" argument). 
such as a "just wants" principle ${ }^{167}$ or some interpretations of Rawls' principles of justice. ${ }^{168}$ To this point, however, the insurance theorist might raise an argument often made by efficiency proponents: to the extent that an efficiency approach raises distributional concerns, tax and transfer rules can address these concerns more effectively or efficiently than can the choice of legal rules. ${ }^{169}$ As applied to the insurance theory, the claim would be that any distributional concerns raised or left unaddressed by the theory could be handled more effectively through programs such as welfare payments, unemployment compensation, or societal health benefits. Whatever the merits of this view generally, ${ }^{170}$ it has little force in the context in which the insurance theory will be applied.

To the extent that injury and disease raise distributional concerns, any social structure must come to grips at some level with the injury or disease itself and its spectrum of consequences: it must verify the existence of the loss, decide whether the loss is of the sort that triggers the program's benefits, and evaluate the consequences of loss without simply using postloss wealth as a proxy for those consequences. ${ }^{171}$

167 For a contractarian argument in favor of a "just wants" principle that is less stringent than Rawls' difference principle, see Baker, supra note 163, at 963-69 (outlining a principle that would guarantee the individual the resources required to lead an acceptably meaningful life in the community).

168 See, e.g., Norman Daniels, Just Health Care $42-48$ (1985) (extending Rawls' theory to the health-care context). Others have argued that Rawls' approach or other contractarian accounts would not support a right to a basic minimum of health care and rehabilitative and supportive services. See, e.g., Allen Buchanan, The Right to a Decent Minimum of Health Care, in President's Commission for the Study of Ethical Problems in Medicine and Biomedical and Behavioral Research, 2 Securing Access to Health Care 207, 222-31 (1983). To the extent one is persuaded that contractarian analyses or other justice arguments support entitlement to basic rehabilitative and supportive services, some of the insurance theory's distributional implications are troubling.

169 See Polinsky, supra note 50, at 124-27; Calabresi, supra note 159 , at 1224 n.36 (describing this argument as a common response to the distributional concerns raised by various effiency standards).

170 For criticism of this point as a general defense of efficiency standards, see Calabresi, supra note 159 , at 1224 n.36.

171 Consider, for example, the social security disability program, the best current example of a compensation program based on an insurance rationale. The program is concerned with risk-spreading for impairments that remove the individual's ability to engage in "substantial gainful activity." See 42 U.S.C. § 423(d) (1988). An enormous administrative structure exists for determining if an individual has sustained one or more of the requisite types of impairment and if that impairment has had the requisite impact. See Jerry L. Mashaw, Bureaucratic Justice: Managing Social Security Disability Claims 18-19 (1983) (describing the massive scope of the social security adjudicative apparatus). 
These determinations, even if governed by relatively general standards (such as schedules), require some level of factfinding about this injury and its consequences. There is no reason to suppose that tax or welfare structures can engage in these inquiries more effectively than whatever compensation structure is at issue. In fact, tax or welfare programs would have to employ an assessment procedure that to some degree duplicates the compensation program's assessment. Such duplication brings substantial costs and few advantages. ${ }^{172}$

In addition to its distributive problems, the insurance theory violates another principle that many contractarian justifications include in some form: antidiscrimination. A contractarian account must begin with a description of the conditions under which the choice of governing principles would be made; most agree that these conditions should include the choosers' ignorance of certain facts concerning their place in society. Thus, an individual cannot know, for example, whether she eventually will suffer serious injury or disease, what sort of injury or disease might befall her, or her pre-injury social situation and level of wealth. ${ }^{173}$ An individual could know, however, certain basic facts about the society and human existence, including the potential for discrimination in various forms against various groups. ${ }^{174}$

Given these starting points, those developing the contractarian meta rule(s) would almost certainly include some sort of antidiscrimination or antisubordination principle, whether expressed as a

172 Many disability analysts have argued for greater integration of programs relating to disability. See Robert R. Humphreys, Disability in America: 1980 and Beyond, in Annual Review of Rehabilitation 1, 7 (Elizabeth L. Pan, Thomas E. Backer \& Carolyn L. Vash eds., 1980); William G. Johnson, Disability, Income Support, and Social Insurance, in Disability Policies and Government Programs 87, 103 (Edward D. Berkowitz ed., 1979) (criticizing current societal disability system for unnecessary duplication, and noting that the administrative technology used in different programs is essentially the same).

173 See Rawls, supra note 161, at 136-42 (describing the "veil of ignorance" under which the original choosers must operate); Sunstein, supra note 156, at 33-34 (describing facts of which citizens would and would not be aware when setting out basic rules governing governmental power).

174 See Rawls, supra note 161 , at $137-38$ (explaining that those choosing the general principles would be aware of general facts about human society, including political affairs, the basis of social organization, and the laws of human psychology); Sunstein, supra note 156, at 33-34 (stating that the original choosers would know that "certain groups may be subject to discrimination"). 
mandate for fair equality of opportunity ${ }^{175}$ or a prohibition on social policies that have the purpose (or effect) of subordinating or denigrating individuals. ${ }^{176}$ Viewed in light of such principles, the insurance theory's unquestioning reliance on preferences that may be substantially shaped by discrimination and devaluation of the disabled is troublesome. And, as we have seen, the way in which the theory uses these preferences has fundamental implications for the basic quality of life of the disabled. The point here is not that an acceptable compensation theory must identify and correct all of the disability-related discriminatory features of the societal landscape. Nonetheless, a theory should not simply build upon that landscape without considering how the compensation structure could be modified to minimize (or at least avoid exacerbating) the effects of those discriminatory features.

\section{CONCLUSION}

Despite its failure to provide an acceptable guide to appropriate compensation, the insurance theory has produced important benefits. It has focused increased attention on the compensatory role of payments for loss. It has directed the flow of the discussion to envisioning approaches that can address the compensatory failings of tort law's "make whole" paradigm. Most importantly, it has begun to ask-however imperfectly - a question whose importance has always been obscured by the tort system's approach: exactly when and how can monetary payments benefit a person who has experienced illness or injury? In a sense, this Article is a complaint about the way the insurance theory asks this question and a claim that the question can be asked and answered in more acceptable ways.

The insurance theory asks and answers this question by focusing on subjective views about the postinjury marginal utility of money as well as the replaceability of particular losses. But the theory's use of the marginal utility variable, I have shown, fails to account for and

175 Rawls' first principle of justice requires that each person "have an equal right to the most extensive total system of equal basic liberties compatible with a similar system of liberty for all." Rawls, supra note 161 at 302 . His second principle requires, in part, that social and economic inequalities be "attached to offices and positions open to all under conditions of fair equality of opportunity." Id.

176 See Baker, supra note 163, at 966 (arguing that a contractarian perspective would support "a prohibition on government action whose meaning or purpose is to show disrespect or to deny people's equality by subordinating them"). 
often exacerbates the effects of disability-related discrimination, omits consideration of some important costs of injury that will fall on people other than the injured individual, and has troublesome distributional implications that cannot be dismissed by citing the availability of tax and transfer schemes. The theory's replaceability query is also flawed, because in many instances it will require resort to evaluative standards outside the notion of subjective replaceability and may turn on preferences influenced by discrimination.

A more defensible approach to compensation in this arena would originate in a rich understanding of the spectrum of injury, disease, and their consequences; the wide range of rehabilitative and supportive options available to address such consequences; the extent and sources of discrimination against the disabled; and the ways in which compensation benefits may take account of such discrimination. On the basis of such a foundation, one could begin to ask about exactly how and when money can benefit individuals who experience illness or injury. ${ }^{177}$ One would find, for example, that in some contexts monetary payments directly and significantly influence fundamental aspects of life quality, including independent functioning, social interaction, and both vocational and nonvocational activities. Other monetary payments, on the other hand, might arguably produce utility of some level, but would not relate to life quality in a fundamental way. Into this category fall Professor Schwartz's example of "mink and caviar" for the person in pain, ${ }^{178}$ payments for past experiences of acute pain, and payments for the relationship that the death of a loved one has destroyed. ${ }^{179}$

177 Although in some respects Professor Weiler embraces the insurance theory, see Weiler, supra note 10, at 56-57, he also seems to support endorsing payments for "rehabilitation and support in the broader sense of the term, helping the accident victim to adjust socially and psychologically, rather than just medically and vocationally, to the new disabled state." Id. at 58.

178 See Schwartz, supra note 9, at 364 .

179 These conclusions about occasions when compensation may not be warranted do not conflict with the conclusions of the insurance theory. See 2 ALI Reporters' Study, supra note 10, at 206, 211 (arguing for excluding payments for some variants of pain and suffering); Weiler, supra note 10, at 57 (listing types of pain and suffering experiences that should not be compensated under an insurance rationale). I nonetheless reject reliance on the insurance theory as the primary guideline for determining when compensation is appropriate and when it is not. As elaborated in the text, I contend that the theory is indeterminate with respect to numerous disability scenarios, and I object to the marginal utility approach to determining compensability. 
Obviously, one could not generate a complete and noncontroversial account of what money can buy, what benefits it yields, and how those benefits compare with others. ${ }^{180}$ But the accounts thus generated could at least be cognizant of the complexities of disability and sensitive to the ways in which discrimination affects the perception and reality of disability. With such accounts in hand, the theorist could outline a compensatory approach that is acceptable in light of one or more normative theories. For example, a theorist guided by a "just wants" contractarian approach could argue against many of the payments that tort law traditionally provides and for payments beyond those allowed by the insurance theory or some nontort programs. ${ }^{181}$

To the extent that the insurance theory has prompted reflection on these issues - the needs of the injured and the ways in which money can address those needs-it has served a valuable function. But the theory's central tools - the marginal utility query and the pecuniarynonpecuniary distinction-are normatively and practically objectionable for the reasons I have described. Thus, relying on the insurance theory for primary guidance about compensatory standards would be a serious mistake; we can and must do better.

180 Even the effort to define and categorize various losses-though often thought to be largely a matter within the province of medicine-is deeply normative. See Ellen S. Pryor, Flawed Promises: A Critical Evaluation of the American Medical Association's "Guides to the Evaluation of Permanent Impairment," 103 Harv. L. Rev. 964 (1990) (book review) (arguing that the American Medical Association's "objective" and "medical" impairment rating system rests on controversial normative judgments).

181 It is possible to use the theory to provide a supplemental argument against some of these nonpecuniary awards. See e.g., Weiler, supra note 10, at 55-57 (arguing that the insurance theory provides a "powerful argument" against some such recoveries). I have no objection to this use of the theory. I would add, however, that arguments against such recoveries are available for reasons other than the insurance rationale and that the theory still fails to yield meaningful guidance about numerous postinjury scenarios. See supra text accompanying notes 113-32. Hence, I object to the theory when it is offered as a primary guideline for setting the amounts and categories of compensation to be paid. 